\title{
The Activators of Cyclin-Dependent Kinase 5 p35 and p39 Are Essential for Oligodendrocyte Maturation, Process Formation, and Myelination
}

\author{
Fucheng Luo, ${ }^{1}$ Jessie Zhang, ${ }^{1}$ Kathryn Burke, ${ }^{4}$ Robert H. Miller, ${ }^{4}$ and Yan Yang ${ }^{2,3}$ \\ Departments of ${ }^{1}$ Neurosciences and ${ }^{2}$ Neurology, ${ }^{3}$ Center for Translational Neurosciences, Case Western Reserve University, School of Medicine, Cleveland, \\ Ohio 44106, and ${ }^{4}$ Department of Anatomy and Regenerative Biology, George Washington University, Washington, DC 20037
}

The regulation of oligodendrocyte development and myelin formation in the CNS is poorly defined. Multiple signals influence the rate and extent of CNS myelination, including the noncanonical cyclin-dependent kinase 5 (Cdk5) whose functions are regulated by its activators p35 and p39. Here we show that selective loss of either p35 or p39 perturbed specific aspects of oligodendrocyte development, whereas loss of both p 35 and p 39 completely inhibited the development of mature oligodendrocytes and myelination. In the absence of p35, oligodendrocyte differentiation was delayed, process outgrowth was truncated in vitro, and the patterning and extent of myelination were perturbed in the CNS of $p 35^{-1-}$ mice. In the absence of $\mathrm{p} 39$, oligodendrocyte maturation was transiently affected both in vitro and in vivo. However, loss of both p35 and p39 in oligodendrocyte lineage cells completely inhibited oligodendrocyte progenitor cell differentiation and myelination both in vitro and after transplantation into shiverer slice cultures. Loss of p35 and p39 had a more profound effect on oligodendrocyte development than simply the loss of $\mathrm{Cdk} 5$ and could not be rescued by Cdk 5 overexpression. These data suggest $\mathrm{p} 35$ and p39 have specific and overlapping roles in oligodendrocyte development, some of which may be independent of Cdk5 activation.

Key words: Cdk5; maturation; myelination; oligodendrocyte; $35 ; \mathrm{p} 39$

\section{Significance Statement}

The development of oligodendrocytes and myelination is essential for normal CNS function and cyclin-dependent kinase 5 (Cdk5) activity is critical for oligodendrocyte maturation, but how $\mathrm{Cdk} 5$ activity is controlled is unclear. Here we show that the coactivators of Cdk5, p35 and p39, regulate distinct stages of oligodendrocyte development and myelination. Loss of p35 perturbs oligodendrocyte progenitor cell differentiation, whereas loss of p39 delays oligodendrocyte maturation. Loss of both completely inhibits oligodendrogenesis and myelination. Disruption of oligodendrocyte development was more pronounced in $p 35^{-1-} ; p 39$ shRNA cells than loss of Cdk5 alone and could not be rescued by Cdk 5 overexpression, suggesting that p35 and p39 have Cdk5independent roles during oligodendrocyte development. These studies provide novel targets for therapeutic intervention in conditions in which myelination is perturbed.

\section{Introduction}

During CNS development, the generation of oligodendrocytes (OLs) and myelination are tightly regulated, and the failure of myelination or remyelination such as occurs in multiple sclerosis

\footnotetext{
Received June 10, 2015; revised Jan. 25, 2016; accepted Feb. 1, 2016.

Author contributions: F.L., R.H.M., and Y.Y. designed research; F.L., J.Z., K.B., and Y.Y. performed research; F.L., R.H.M., and Y.Y. analyzed data; F.L., R.H.M., and Y.Y. wrote the paper.

This work was supported by National Institutes of Health Grants NS077942 (Y.Y.) and NS3800 (R.H.M.). We thank Dr. James A. Bibb (University of Texas Southwestern Medical Center, Dallas, TX) for giving $\mathrm{p} 39$ heterozygous as a gift. The authors declare no competing financial interests.

Correspondence should be addressed to either of the following: Dr. Yan Yang, Department of Neurology, Case Western Reserve University, 10900 Euclid Avenue, Cleveland, 0H 44106, E-mail: yxy33@case.edu; or Dr. Robert H. Miller, Department of Anatomy and Regenerative Biology, George Washington University, Washington, DC 20037, E-mail: rhm3@email.gwu.edu.

DOI:10.1523/JNEUROSCI.2250-15.2016

Copyright $\odot 2016$ the authors $\quad 0270-6474 / 16 / 363024-14 \$ 15.00 / 0$
}

ultimately results in loss of axonal function. Multiple intracellular and extracellular signals modulate CNS myelination ( $\mathrm{He}$ and $\mathrm{Lu}, 2013$ ). These include transcription factors (e.g., Olig2, Nkx2.2, Sox10, and MRF; Zhou et al., 2001; Koenning et al., 2012; Wang et al., 2014), growth factors (e.g., PDGF-AA, Shh, FGF, neuregulin-1, IGF-1, and neurotrophins; Baron et al., 2000; Miller, 2002; Sussman et al., 2002), and signaling molecules (e.g., CXCL1, BMP, PI3K/Akt/mTOR, Gsk-3 $\beta$, Notch, and Wnts; Genoud et al., 2002; Flores et al., 2008; Narayanan et al., 2009; Azim and Butt, 2011; Tawk et al., 2011; Lebrun-Julien et al., 2014). How these signals are integrated is unclear, but one potential point of integration is the noncanonical kinase cyclin-dependent kinase 5 (Cdk5).

In neurons, Cdk5 influences multiple cellular functions, including differentiation, migration, cortical lamination, axon 
guidance, cytoskeletal organization, membrane trafficking, and synaptic plasticity (Su and Tsai, 2011; Cheung and Ip, 2012; Yang et al., 2013). Neuronal circuitry is also dependent on Cdk5 (Cheung and Ip, 2007; Lai et al., 2012) because Cdk5 is required for learning and memory formation and hippocampal plasticity (Guan et al., 2011; Lai et al., 2012). More than 50 substrates of Cdk5 have been reported, including $\beta$-catenin, FAK, Tau, Paxilin, WAVE2, p27 (kip1), msds3, and p53, as well as several regulatory signaling pathways (Gsk-3 $\beta$, JNK, p38MAPK, Wnt/ $\beta$ catenin, and Notch; Smith et al., 2001; Su and Tsai, 2011; Yang et al., 2013). Although Cdk5 activity is required for OL development, which of these signals are necessary and whether there is relative engagement or hierarchy of the signaling pathways and substrates in myelination and myelin repair is unclear. Likewise, how Cdk5 activity is regulated in OL lineage cells is not fully understood.

Two proteins, p35 and p39, regulate Cdk5 activity (Ko et al., 2001). Mice lacking p35 mice display a severe phenotype, including cortical lamination defects and abnormal hippocampus morphology, and suffer from sporadic adult lethality and seizures, whereas $p 39^{-1-}$ mice are viable, fertile, and have no apparent phenotype (Chae et al., 1997; Ko et al., 2001). Both p35 and p39 transcripts are first detected at E12, and mRNA expression increases substantially by E15-E17, although the peak of p39 expression in the CNS occurs postnatally. p35 and p39 expression are observed in multiple non-neuronal cells, such as $\mathrm{T}$ cells, macrophages, muscle cells, neutrophils, and pancreatic cells (Contreras-Vallejos et al., 2012). They regulate gene expression, glucose-inducible secretion, hematopoietic cell differentiation, vascular angiogenesis, cell migration, and immune responses (Arif, 2012).p35 and p39 may also be expressed in astrocytes and microglia (He et al., 2007; Fang et al., 2015). Deletion of p39 but not p35 has been shown to modulate OL differentiation and myelin repair (Bankston et al., 2013). Although these studies implicate p39 and to a lesser extent p35 in the generation of OLs and myelination, which aspects and stages of OL development are affected by each of the activators are poorly understood.

Here we show that p35 and p39 regulate distinct Cdk5 activities in OL development. In the absence of p35, the differentiation of OLs and patterning of myelination is disrupted. In contrast, loss of p39 results in delayed OL maturation in vitro and transient reduction in myelin basic protein (MBP) expression in vivo. Lack of both p39 and p35 in OL lineage cells completely blocked oligodendrocyte progenitor cell (OPC) differentiation and myelination in vitro and in demyelinating shiverer slice cultures. Unexpectedly, the disruption of OL development was more pronounced in the absence of p35/p39 than in the absence of Cdk5 alone and could not be rescued by overexpression of Cdk5. Together, these data suggest that p35 and p39 activate distinct Cdk5 functions that modulate distinct stages of OL development and may also have non-Cdk5 targets.

\section{Materials and Methods}

Animals. All animal care and animal procedures were approved by the Institutional Animal Care and Use Committee of Case Western Reserve University School of Medicine. Heterozygous $p 35^{+/-}$mice (stock \#004163; The Jackson Laboratory) were expanded and genotyped by PCR as described previously (Kwon and Tsai, 1998). $p 39^{+/-}$animals (a gift from Dr. James Bibb, University of Texas Southwestern Medical Center, Dallas, TX) were genotyped using PCR as described previously (Ko et al., 2001). The $p 35^{-/-}$and $p 39^{-/-}$mice are targeted deletions of the p35 or p39 gene. $C d k 5^{+/-}$mice were obtained from Dr. Karl Herrup (Hong Kong University of Science and Technology, Sai Kung, Hong Kong), and individual offspring were genotyped as described previously
(Cicero and Herrup, 2005). Shiverer mice (C3Fe.SWV-MBP ${ }^{\text {shi }} / J$ ) and C57BL/6 mice were purchased from The Jackson Laboratory. Both male and female mice were included in this study.

Purified OPCs culture. Immunopanning purification of OPCs was based to the previous protocol with slight modifications (Barres et al., 1992). Cell culture dishes were precoated with secondary antibody IgM (10 $\mu \mathrm{g} / \mathrm{ml}$; catalog \#55460; Millipore) in $50 \mathrm{~mm}$ Tris- $\mathrm{HCl}$ and monoclonal antibody A2B5. Dissociated cells were incubated in the precoated culture dishes for $30 \mathrm{~min}$ at $37^{\circ} \mathrm{C}$, and non-adherent cells were removed. OPCs were released by $0.05 \%$ trypsin in DMEM at a purity of $\sim 96 \%$. Cells were expanded in media supplemented with 5 $\mathrm{ng} / \mathrm{ml}$ neurotrophin-3, $10 \mathrm{ng} / \mathrm{ml} \mathrm{CNTF}, 20 \mathrm{ng} / \mathrm{ml} \mathrm{bFGF}$, and $20 \mathrm{ng} / \mathrm{ml}$ PDGF-AA.

Differentiation of OPCs. To induce OPC differentiation, cells were switched to media lacking bFGF and PDGF-AA, with the addition of thyroid hormone ( $40 \mathrm{ng} / \mathrm{ml}$; Sigma). OPCs were allowed to differentiate for 2, 4, and $6 \mathrm{~d}$ and labeled with $\mathrm{O}_{4}{ }^{+}, \mathrm{O} 1^{+}$, and anti-MBP antibodies. The percentage of positive $\mathrm{O}^{+}, \mathrm{O}^{+}{ }^{+}$, and $\mathrm{MBP}^{+}$cells were calculated and compared between genotypes. To quantify cellular complexity and maturation of individual OPCs/OLs, the number of the primary processes of $\mathrm{O}^{+}$cells (at least 40-50 cells per coverslip) was counted, and the average footprint area of $\mathrm{MBP}^{+}$cells was measured using NIH Image $\mathrm{J}$ software. For the footprint analyses, at least 40 individual $\mathrm{MBP}^{+}$cells were measured. Statistical analysis was performed using two-way ANOVA tests for comparison. $p$ values $<0.05$ were considered statistically significance.

Transfection of OPCs. Transfections were performed using the Amaxa Nucleofector electroporation system using the program O-17 according to the instructions of the manufacturer (Amaxa). Purified OPCs were centrifuged at $1200 \mathrm{rpm}$ for $5 \mathrm{~min}$, and the cell pellet was resuspended to a density of $3 \times 10^{6}$ cells $/ 100 \mu \mathrm{l}$ in OPC Nucleofection solution (Amaxa Oligodendrocyte Nucleofector kit; Amaxa), with shRNA for p39-EGFP $(2 \mu \mathrm{g} / \mu \mathrm{l})$, Cdk5-EGFP, control pEGFP-C1 plasmid, or a scrambled plasmid. Transfected cells were added to organotypic slice cultures of shiverer or plated on a poly-L-lysine-coated coverslip at $3 \times 10^{4} /$ coverslip and grown in differentiated media for $2-6 \mathrm{~d}$ before maturation and myelination analyses.

Organotypic cerebellar slice culture. The cerebellum of P6-P7 wild-type (WT) or shiverer mice was dissected, and 300- $\mu \mathrm{m}$-thick sagittal cerebellar slices were sectioned using a Leica Vibratome. Slices were placed into cell-culture inserts (Millicell-CM; Millipore) and grown in medium containing basal medium Eagle medium supplement with 25\% horse serum, $0.5 \%$ glucose, $2.5 \%$ HBSS, and $1 \%$ L-glutamine for $2 \mathrm{~d}$ as described previously (Najm et al., 2011, 2015). To assay the effects of loss of p35 and p39 on maturation and myelination, purified $p 35^{-1-}$ or $p 39^{-1-}$ OPCs were injected into shiverer cerebellar slices at a cell density of $2 \times 10^{5}$. For deletion of both $\mathrm{p} 35$ and $\mathrm{p} 39$, OPCs from $p 35^{-1-}$ were transfected with shRNA for p39-EGFP plasmid, injected into slices, and allowed to mature and myelinate for $10 \mathrm{~d}$.

For MBP detection, slices were fixed in $4 \%$ paraformaldehyde and delipidated with $95 \%$ ethanol and 5\% acetic acid for 20 min. Primary antibodies (MBP, SMI-99, 1:500 from Covance; Neurofilament 200, 1:250 from Sigma; and GFP, 1:250 from Invitrogen) were incubated overnight at $4^{\circ} \mathrm{C}$, followed by the appropriate secondary antibodies of either goat anti-mouse or anti-rabbit IgG Alexa Fluor 488 or 594 (1:500; Invitrogen). Slices were mounted and analyzed using a Leica DFC 500 fluorescence microscope. Quantitative measurement of MBP intensity in the slices was accomplished using the EBImage imaging software (http://master.bioconductor.org/packages/release/bioc/html/EBImage. html) and run through the statistical programming environment $\mathrm{R}$ as described by the Kumlesh group (Sheridan and Dev, 2012; Pritchard et al., 2014). At least six to seven slices from each group and four to six images per slice were captured and used for imaging analysis. The total fluorescence intensity of MBP was analyzed and normalized to the intensity of background staining. To measure the amount of MBP (red) colocalized with neurofilament 200, labeling of neurofilament 200 (green) was used as a "mask" and the intensity of MBP was assayed. Data comparing the fluorescence intensity of MBP in each experimental group were normalized to controls and presented as bar graphs. 
A
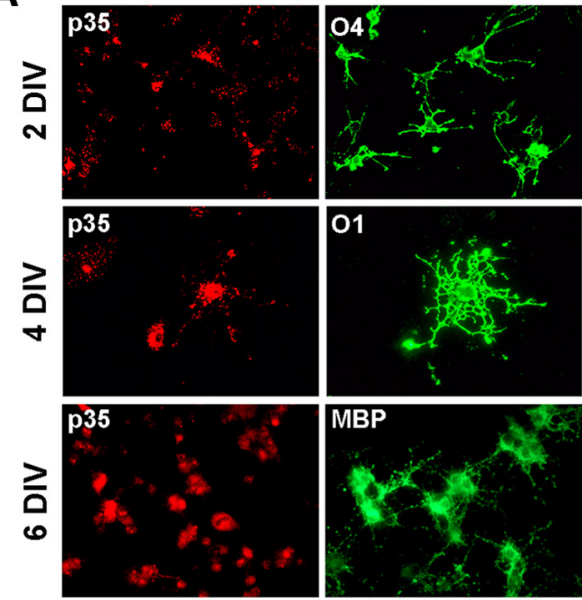

$\mathrm{C}_{\mathrm{a}}$

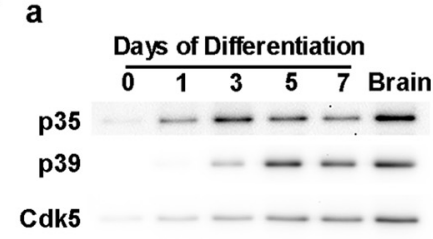

$\beta$-actin b

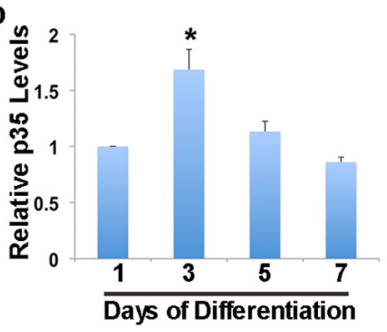

B
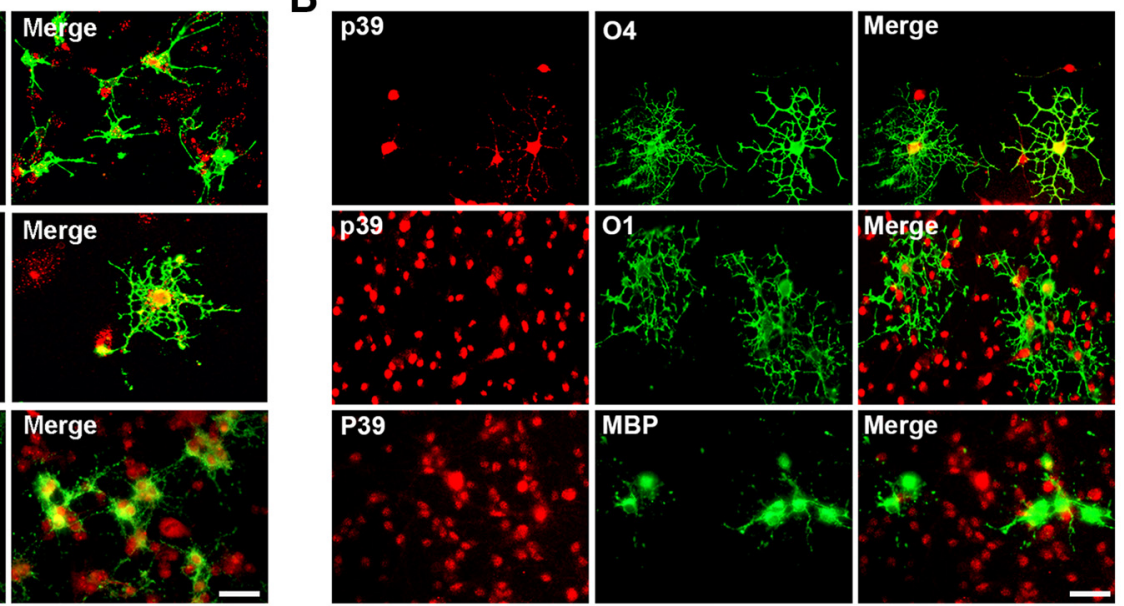

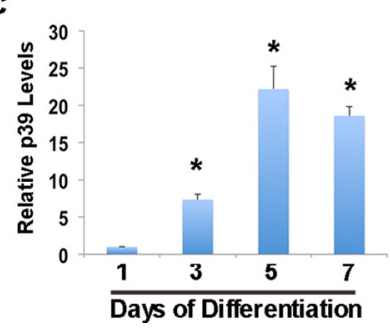

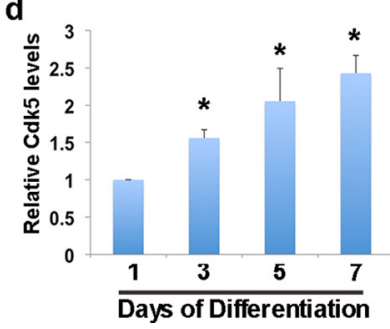

Figure 1. Expression of $\mathrm{p} 35$ and $\mathrm{p} 39$ in the distinct stages of OPCs and mature $0 \mathrm{Ls}$. Immunocytochemical staining demonstrating p35 $(\boldsymbol{A})$ and p39 $(\boldsymbol{B})$ expression in purified $04^{+}, 01^{+}$, and $\mathrm{MBP}^{+}$cells. Western blots revealed a relative abundance of p35, p39, and Cdk5 in OPCS/OLs during differentiation at 3,5, and $7 \mathrm{~d}(\mathbf{C a})$. Quantification of expression levels is shown in bar graphs $(\boldsymbol{B} \boldsymbol{b}-\boldsymbol{B d})$. Values represent mean $\pm \operatorname{SEM}(n=3) .{ }^{*} p<0.05$. Scale bars: $\boldsymbol{A}, \boldsymbol{B}, 50 \mu \mathrm{m}$.

Immunocytochemical staining of purified OPCs/OLs. Labeling with monoclonal antibodies $\mathrm{O} 4$ and $\mathrm{O} 1$ (1:10) were performed on live cells (O4 at 1:5 and $\mathrm{O} 1$ at 1:10), followed by secondary antibody goat antimouse IgM Alexa Fluor 488 or 594 (1:500; Invitrogen). For double labeling, cells were incubated with the second primary antibodies against $\mathrm{p} 35$ or p39 (1:100; Abcam) or rabbit anti-Cdk5 (1:100; Santa Cruz Biotechnology) or MBP (SMI-99, 1:500; Covance) overnight at $4^{\circ} \mathrm{C}$, followed by secondary antibodies conjugated with Alexa Fluor 488 or 594. Cells were mounted with Vectashield mounting medium with DAPI (Vector Laboratories).

Immunohistochemical staining of frozen sections. Mice were anesthetized with avertin and perfused with PBS and 4\% paraformaldehyde. Dissected brain were postfixed in $4 \%$ paraformaldehyde overnight at $4^{\circ} \mathrm{C}$ and equilibrated in $20 \%$ sucrose. Coronal cryosections of brains $(20 \mu \mathrm{m})$ were pretreated with Reveal Decloaker Solution (Biocare Medical) for antigen retrieval according to the instructions of the manufacturer. After blocking, sections were incubated with the primary antibodies (MBP, SMI-99, 1:500 from Covance; Olig2, 1:250 from Millipore; and CC1, 1:250 and Neurofilament 200, 1:250 from Sigma), followed by appropriate secondary antibodies. Sections were counterstained with DAPI (1:1000; Sigma) and mounted with mounting medium (Vector Laboratories). All images were taken and analyzed using a Leica DFC500 fluorescence microscope.

Electron microscopy analysis. For ultrastructural analyses, anesthetized animals were perfused with $2 \%$ glutaraldehyde/4\% paraformaldehyde in $0.1 \mathrm{~m}$ sodium carcodylate buffer, $\mathrm{pH} 7.4$ (Electron Microscopy Sciences). Tissue was postfixed in $1 \% \mathrm{OsO}_{4}$ for $2 \mathrm{~h}$, and coronal sections $(500 \mu \mathrm{m})$ containing the corpus callosum were prepared (Leica Vibratome), dehydrated, stained with saturated uranyl acetate, and embedded in a Poly/Bed812 resin (Polysciences). Thick sections $(1 \mu \mathrm{m})$ were cut and stained with toluidine blue, and matched areas were selected for electron microscopy (EM). Ultrathin sections $(0.1 \mu \mathrm{m})$ were cut and visualized using an electron microscope (Jeol 100CX) at $80 \mathrm{kV}$. $G$ ratios were calculated from at least 50-100 randomly selected myelinated axons.
Crosslink immunoprecipitation and kinase assay of Cdk5 activity. The Pierce Crosslink immunoprecipitation kit (catalog \#26147; Thermo Fisher Scientific) was used for protein immunoprecipitation according to the instructions of the manufacturer. Proteins were extracted from cell lysates and precleaned using control agarose resin to reduce nonspecific binding. Cdk5 antibody was preconjugated to Pierce Protein A/G Plus Agarose and crosslinked by adding disuccinimidyl suberate crosslinker in a Pierce Spin Column. Five hundred micrograms of proteins of precleaned lysates were loaded to the Cdk5 antibody-crosslinked resin in the column and incubated overnight at $4^{\circ} \mathrm{C}$. After elution of Cdk5 antigen from the column, kinase buffer (catalog \#9802S; Cell Signaling Technology) containing Histone H1 (catalog \#14-155; Millipore) and $20 \mu \mathrm{g}$ of ATP (catalog \#9804S; Cell Signaling Technology) was added to Cdk5 antigen elution, and the kinase activity of Cdk5 was measured with antiCdk5 immunoprecipitates using Histone $\mathrm{H} 1$ as a substrate. The levels of phosphorylated Histone $\mathrm{H} 1$ were determined by Western blots using phosphorylated antibody of MAPK/Cdk (1:1000; Cell Signaling Technology), which recognizes the phosphorylated sites of Histone $\mathrm{H} 1$, and the intensity of bands was analyzed by NIH ImageJ. Three separate experiments were performed, and the intensity of bands was quantified by NIH ImageJ.

Biochemical analysis: Western blots. Purified OPCs or subcortical white matter samples were homogenized in RIPA lysis buffer containing protease and phosphatase inhibitor mixture, and equal amounts of protein were loaded, separated by $15 \%$ SDS-PAGE, and transferred to PVDF membranes. The membranes were blocked in PBS buffer containing $0.1 \%$ Tween 20 and $5 \%$ BSA for $2 \mathrm{~h}$, incubated with primary antibodies overnight at $4^{\circ} \mathrm{C}$, followed by secondary appropriate antibodies conjugated to HRP. The following primary antibodies were used: p39 (1:1000; Abcam), p35 (1:1000; Millipore), Cdk5 (1:1000; Santa Cruz Biotechnology), p-Cdk5 (Tyr15, 1:500; Santa Cruz Biotechnology), MBP (1:1000; Covance), Akt (1:1000; Cell Signaling Technology), p-Akt (Ser473, 1:1000; Cell Signaling Technology), Gsk-3 $\beta$ (1:1000; Millipore), p-Gsk-3 $\beta$ (Ser 9, 1:1000; Cell Signaling Technology), CREB (1:1000; Cell Signaling Technology), p-CREB (Ser 133, 1:1000; Cell Signaling Technol- 

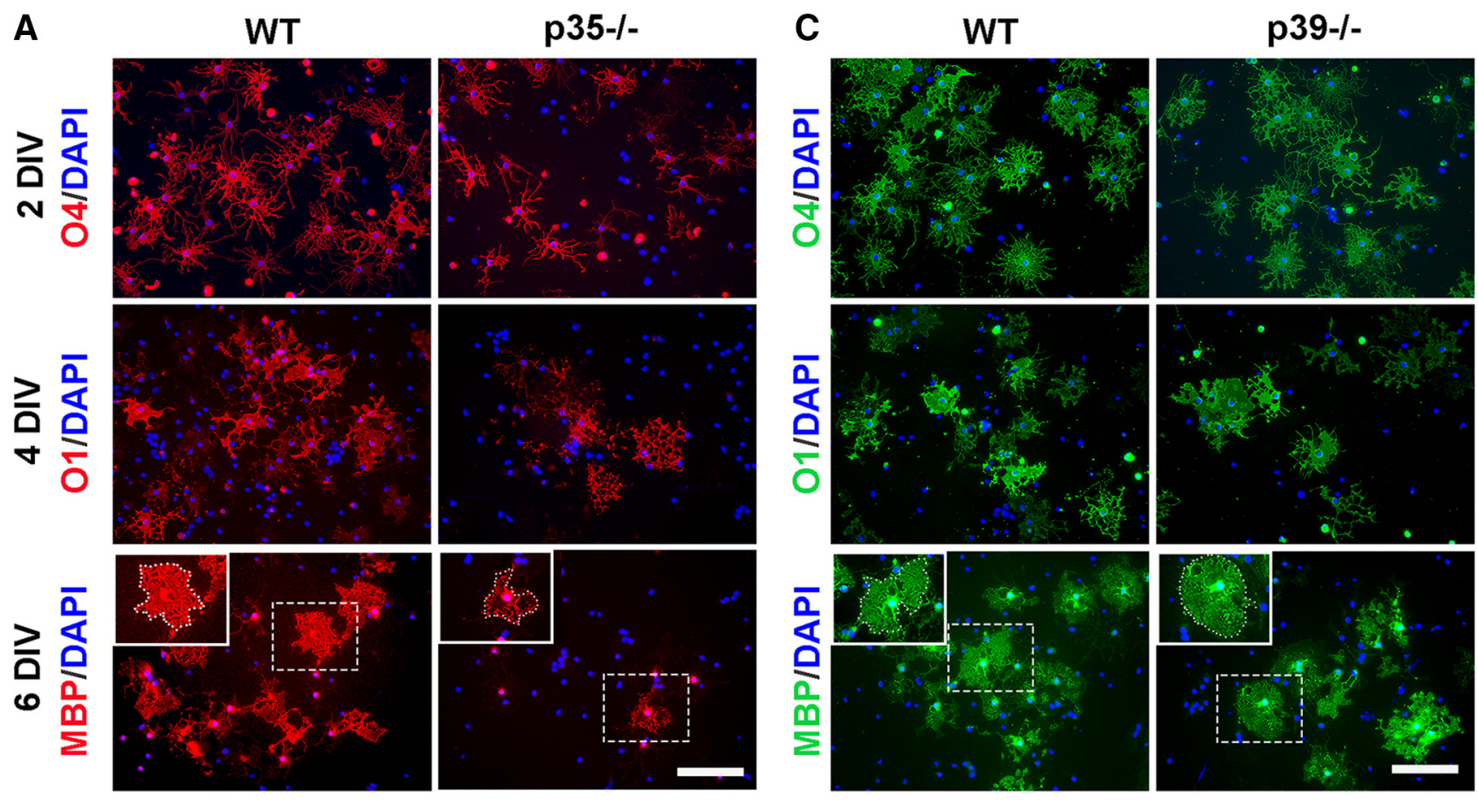
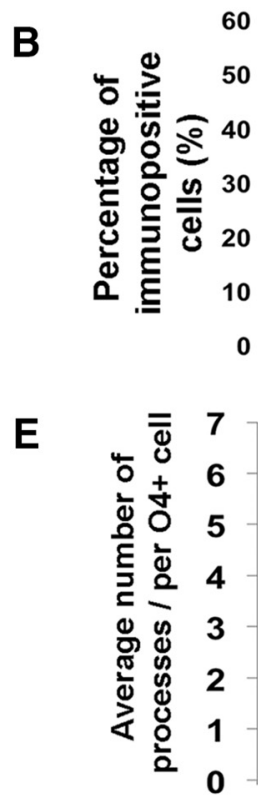

$\mathbf{F}$

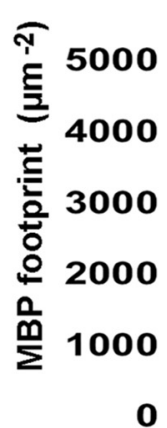

\pm WT $=\mathrm{p} 35 \%$

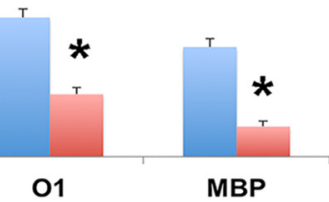

04

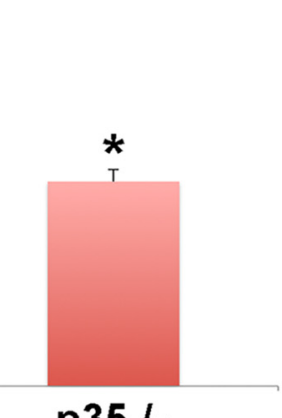

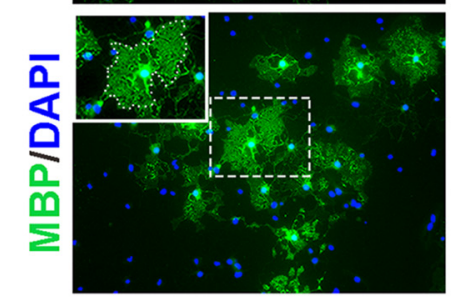
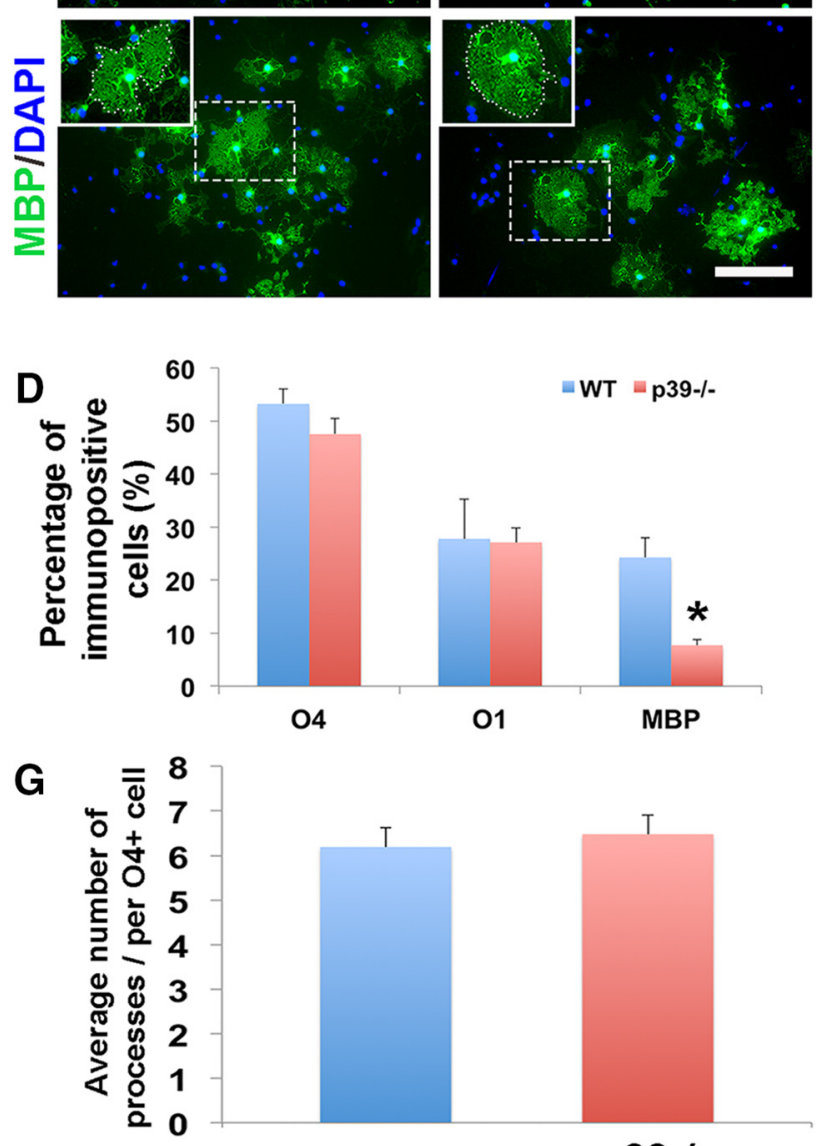

H

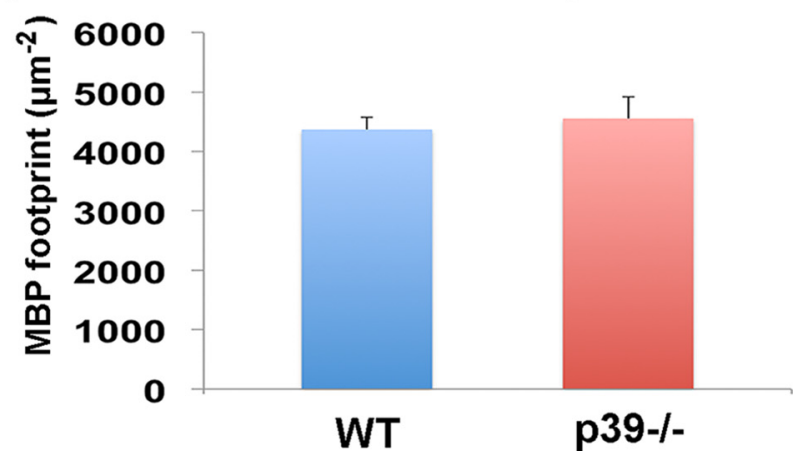

Figure 2. Loss of $\mathrm{p} 35$ or $\mathrm{p} 39$ affects distinct stages of OPC differentiation and $0 \mathrm{~L}$ maturation. $A$, Comparison of the maturation of WT and $p 35^{-/-}$OL lineage cells after switching to differentiation medium. In purified $p 35^{-1-}$ OPC cultures, there is a reduction in the proportion of 01 ( 4 DIV), MBP ${ }^{+}\left(6\right.$ DIV), and reduced primary cellular processes of early $04^{+}(2 \mathrm{DIV})$ cells compared with WT OPCS. B, Quantitation of the relative proportion of maturing $0 \mathrm{Ls}$ in WT and $p 35^{-/-}$cultures. C, In $p 39^{-/-}$OPCs, no changes were seen in early $04^{+}$and (Figure legend continues.) 
A

A $\quad$ P7

P7 P14

P14 P21

CC1

Olig2 $\frac{1 \mathrm{M}}{\mathrm{CC} 1}$
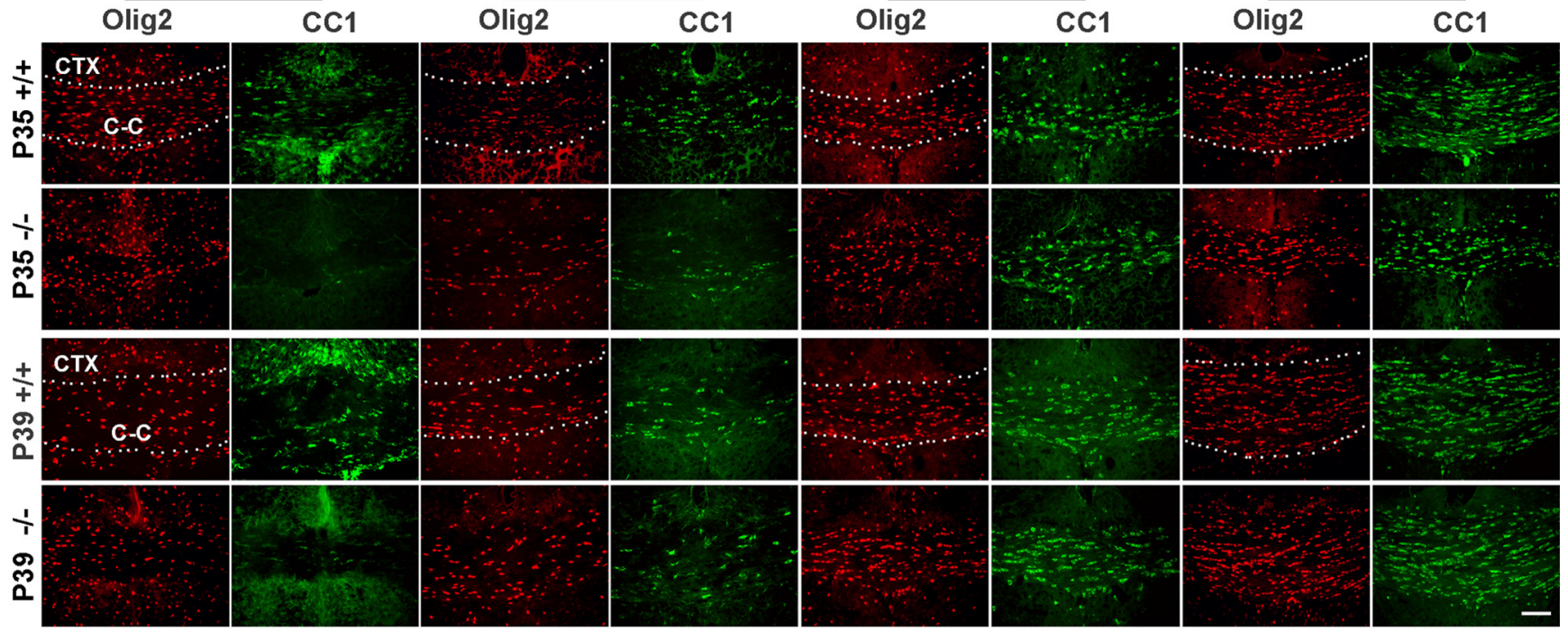

B
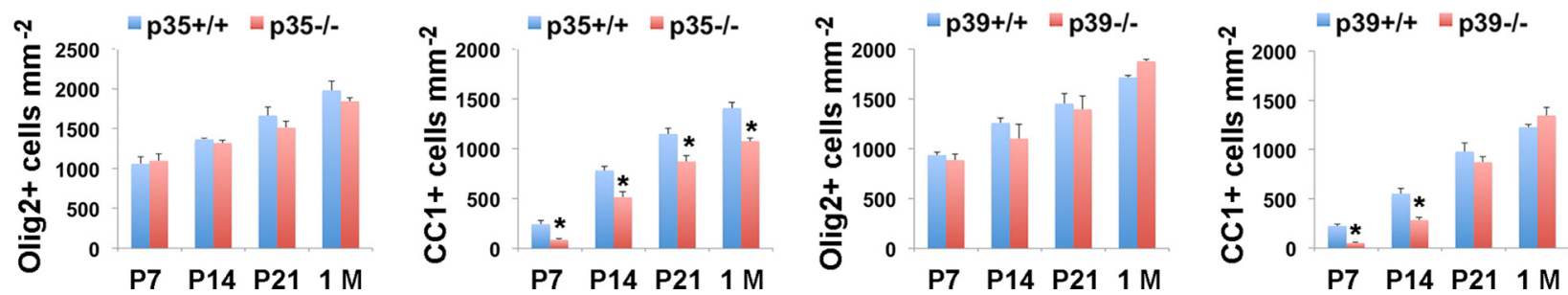

Figure 3. Characterization of $\mathrm{OL}$ development in the brains of $p 35^{-/-}$and $p 39^{-/-}$mice. Double labeling with 0 lig 2 and $C \mathrm{CC} 1$ antibodies reveals a significant reduction in the number of CC1 + cells but only a slight reduction of Olig2 ${ }^{+}$cells during development in the $p 35^{-/-}$animals at ages of P7, P14, P21, and 1 month compared with WT controls (A, top 2 panels in $\left.\boldsymbol{A}\right)$. In $p 39^{-/-}$mice, a reduced number of $\mathrm{CC}^{+}$cells was seen only at P7, and no significant differences were detected between WT and $p 39^{-/-}$animals at the ages of P14, P21, and 1 month $(\boldsymbol{A}$, bottom 2 panels). Quantitative data are shown in $\boldsymbol{B} . n=3-4$ animals were used from each genotyped group of animals. Values are mean \pm SEM. ${ }^{*} p<0.05$. Scale bar (in $\boldsymbol{A}$ ): $100 \mu \mathrm{m}$.

ogy), $\beta$-catenin (1:1000; BD Biosciences), $\mathrm{p}$ - $\beta$-catenin (Ser33/37/Thr41, 1:500; Cell Signaling Technology), and $\beta$-actin (1:1000; Santa Cruz Biotechnology). The density of bands was quantified using NIH ImageJ software.

Quantification and statistical analysis. Blinded counts of cultured cells and cells in matched locations of frozen sections were performed on at least three coverslips or sections per condition from three individual animals using a Leica fluorescence microscope. Six to seven fields were selected randomly and counted on each coverslip or section. The percentage of immunopositive cells were calculated and compared between WT and $p 35^{-/-}$or $p 39^{-/-}$animals. To quantify the cytoarchitecture of OLs, the number of primary processes, and the average footprint area of MBP, at least 40-50 individual ${ }^{+}{ }^{+}$or $\mathrm{MBP}^{+}$cells from each genotype were used for analysis by NIH ImageJ. The relative fluorescence intensity of myelin in slice cultures was measured using EBImage software. All data are presented as mean \pm SEM. Statistical analysis was performed using two-way ANOVA tests for comparison. $p$ values $<0.05$ were considered statistically significant.

(Figure legend continued.) $\quad 01^{+} \mathrm{OPC}$, but significant reduction of $\mathrm{MBP}^{+}$was detected after 6 din differentiation medium compared with WT OPCS. Quantification of the relative proportion of maturing $0 \mathrm{Ls}$ in WT and $p 39^{-1-}$ cultures are shown in $\mathbf{D .}$. $-\mathbf{G}$, Comparison of the average number of primary cellular processes of immunostained $04^{+}$cells between $W T, p 35^{-1-}(\boldsymbol{E})$, or $p 39^{-/-}$OPCS $(\mathbf{G}) ; \boldsymbol{F}-\boldsymbol{H}$, the size of $\mathrm{MBP}^{+}$footprints is different between WT, $p 35^{-/-}$, or $p 39^{-1-}$ cells. $n=40-50$ individual $04^{+}$or $\mathrm{MBP}^{+}$cells from at least six to seven fields for each genotype. Values are mean \pm SEM of three independent experiments. ${ }^{*} p<0.05$. Scale bars: $A, C, 100 \mu \mathrm{m}$

\section{Results}

The expression of p35 and p39 in OL lineage cells

To determine the temporal expression of the C $\mathrm{dk} 5$ activators p35 and p39 in cells of the OL lineage, their expression was assayed in OPCs and differentiated OLs. Expression of p35 and p39 was detected in multiple stages of OL lineage cells (Fig. $1 A, B$ ). Both p35 and p39 were expressed in the majority of $4^{+}$OPCs, immature $\mathrm{O}^{+}{ }^{+}$, and mature $\mathrm{MBP}^{+}$OLs (Fig. $1 A, B$ ). Western blot analysis confirmed the expression of p35 and p39 in purified OPCs (Fig. 1C). After switching to differentiation media, p35 was detected as early as $1 \mathrm{~d}$ and increased significantly up to $3 \mathrm{~d}$ of differentiation before decreasing at 5 and $7 \mathrm{~d}$ of differentiation (Fig. $1 \mathrm{Ca}, \mathrm{Cb}$ ). The expression of $\mathrm{p} 39$ was delayed compared with p35. After $1 \mathrm{~d}$ of differentiation, p39 was barely detectable and levels increased significantly by 5 and $7 \mathrm{~d}$ of differentiation (Fig. $1 C c$ ). Consistent with previous studies (Tang et al., 1998; Bankston et al., 2013), the expression of Cdk5 was increased throughout the differentiation interval (Fig. $1 C d$ ). These results demonstrate that both p35 and p39 are expressed in the OL lineage, and the differential timing of their expression suggests they modulate distinct aspects of Cdk5 function.

\section{Distinct roles for p35 and p39 in OL differentiation}

Both p35 and p39 are coactivators of Cdk5, which has been shown to regulate OL development, myelination, and remyelination (Miyamoto et al., 2007; Bankston et al., 2013). To define the specific roles of p35 and p39 in OL development, OPCs were 
A

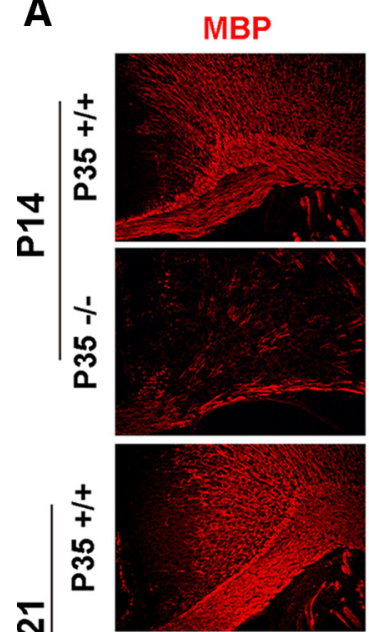

กิ
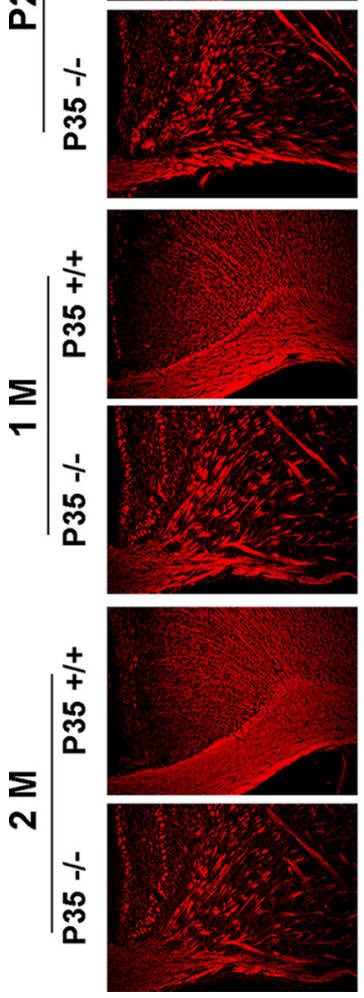

NF 200
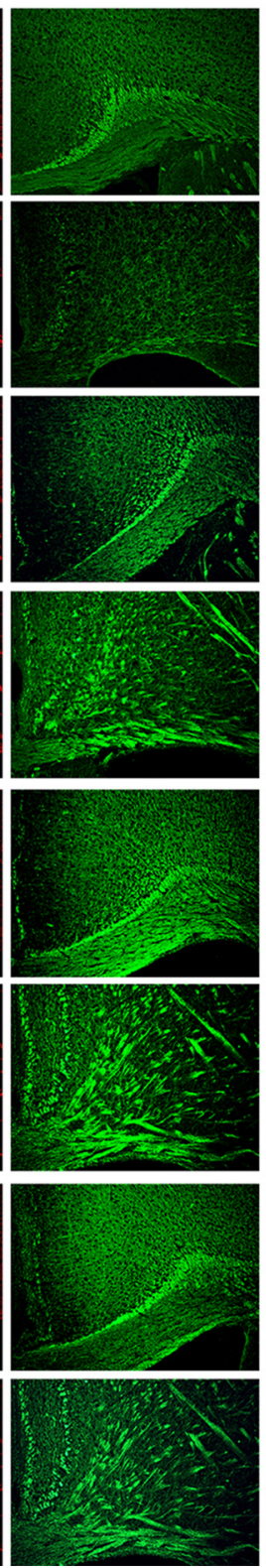

MBP/NF 200
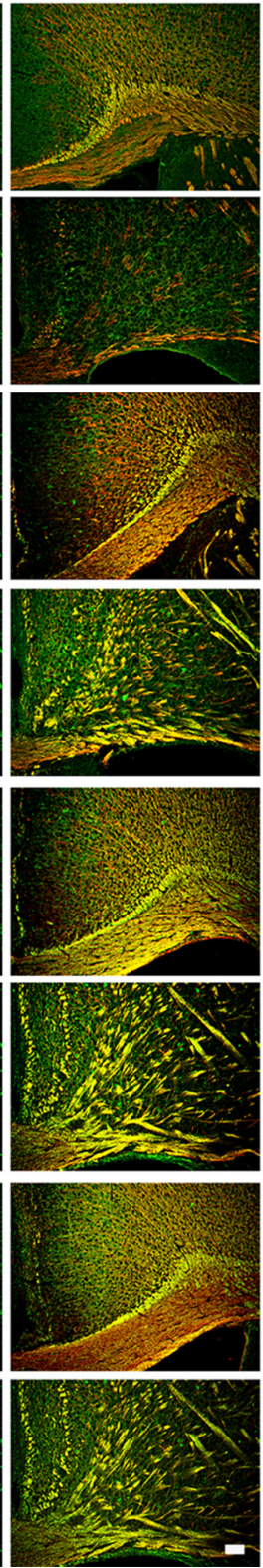

B
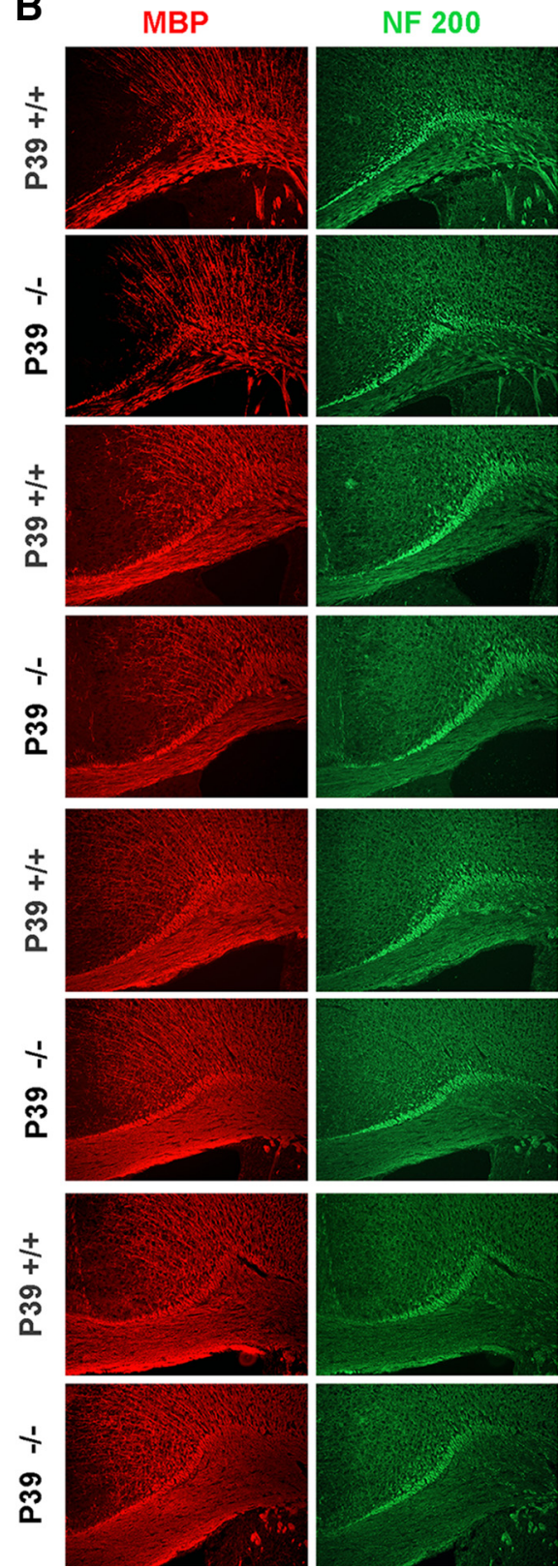
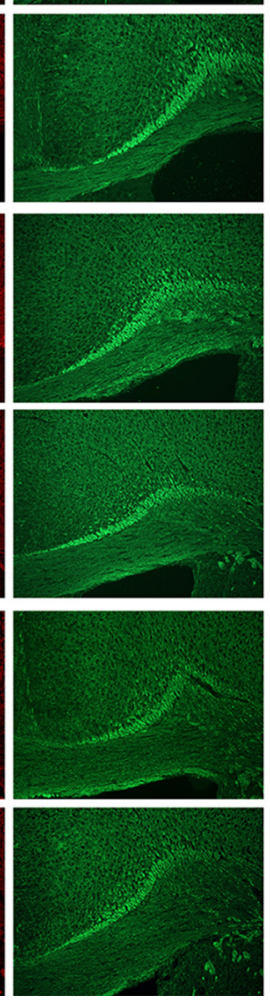

MBP/NF 200
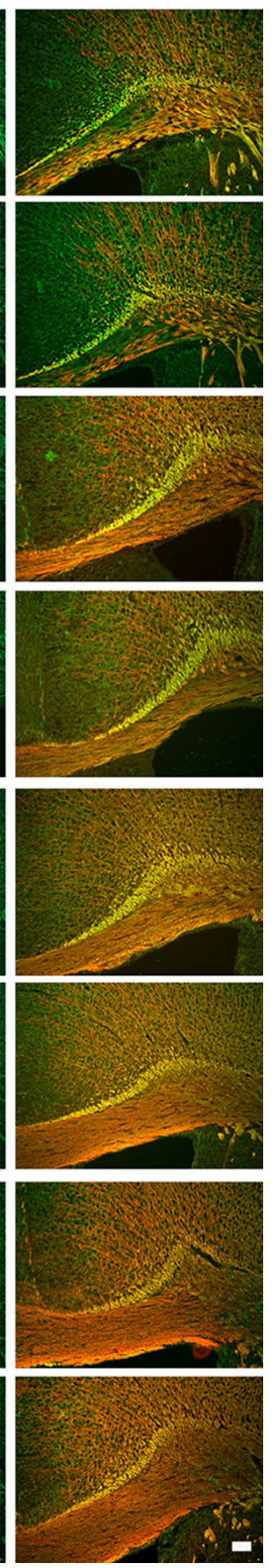

Figure 4. Characterization of myelination in the brains of $p 35^{-/-}$and $p 39^{-/-}$mice. Reduction of MBP (red) myelin expression in the cortex and corpus callosum and disrupted pattern of axonal projections stained with neurofilament (NF; green) at the ages of P14, P21, 1 month, and 2 months in $p 35^{-1-}$ mice compared with age-matched WT controls (A). Reduced MBP expression was only observed in $p 39^{-/-}$mice at age P14, and no significant differences were detected in $p 39^{-/-}$mice at ages P21, 1 month, and 2 months (B). Scale bar: $\boldsymbol{A}, \boldsymbol{B}, 100 \mu \mathrm{m}$.

purified from the corpus callosum of $\mathrm{P} 2 \mathrm{p} 35^{-/-}$and $p 39^{-/-}$animals and their development compared with WT cells. Compared with WT OPCs, the differentiation of $p 35^{-/-}$cells was delayed (Fig. 2). At $2 \mathrm{DIV}$, the proportion of $\mathrm{O}^{+}{ }^{+}$cells was similar (Fig. $2 A$ ), although $p 35^{-/-}$cells had a less complex morphology (Fig. $2 A)$. By $4 \mathrm{~d}$ of differentiation, the proportion of $p 35^{-/-}$expressing $\mathrm{O} 1$ was significantly reduced compared with WT controls ( $p 35^{-/-}, 12 \pm 2 \%$; WT, $29 \pm 2 \%$; Fig. $\left.2 A, B\right)$ and, by $6 \mathrm{~d}$ of differentiation, the proportion of $p 35^{-/-}$cells expressing MBP was significantly reduced compared with WT $\left(p 35^{-/-}, 2 \pm 1 \%\right.$; WT, $\left.20 \pm 2 \%\right)$, suggesting that $\mathrm{p} 35$ plays a role during the differentiation and maturation of OLs (Fig. $2 B$ ). Parallel studies with OPC purified from $p 39^{-/-}$animals demonstrated a selective effect on the maturation of OLs to $\mathrm{MBP}^{+}$cells $\left(p 39^{-/-}, 8 \pm 1 \%\right.$; WT, $\left.28 \pm 4 \%\right)$ but no signifi- cant effect on the proportion of $\mathrm{O}^{+}{ }^{+}$or $\mathrm{O} 1^{+}$cells (Fig. $2 C, D$ ). The loss of p35 and p39 also had differential effects on the morphology of OPCs and OLs. In $p 35^{-/-} \mathrm{O} 4^{+}$cells, the cellular complexity was reduced and the average number of primary processes of $\mathrm{O}^{+}$cells was significantly less $\left(p 35^{-/-}\right.$, $4 \pm 1$; WT, $5.7 \pm 1$; Fig. $2 E$ ). Likewise, the "footprint" of $\mathrm{MBP}^{+}$cells was significantly smaller (Fig. $2 F$ ). In contrast, no significant differences in the average number of the primary processes of $\mathrm{O}^{+}$cells or the MBP cell footprint were detectable in $p 39^{-1-}$ cells compared with WT controls (Fig. 2G,H). These data suggest that p35 and p39 activate distinct functions of Cdk5 that regulate OL development at different stages. Whereas p35 promotes the elaboration of branches and processes of OPCs and OLs, the role of p39 is restricted to regulating the maturation of OLs. 


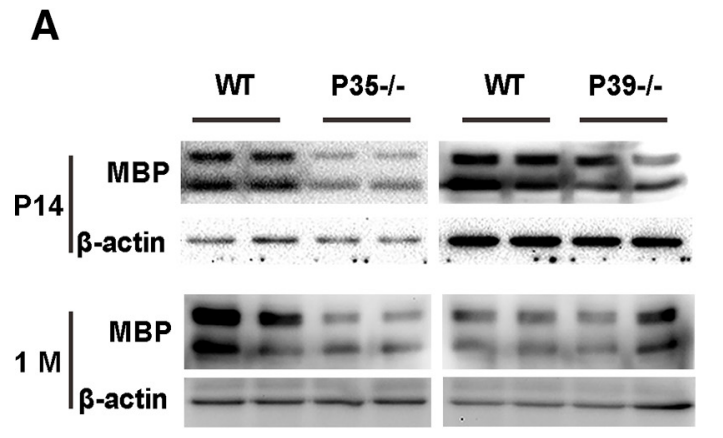

D

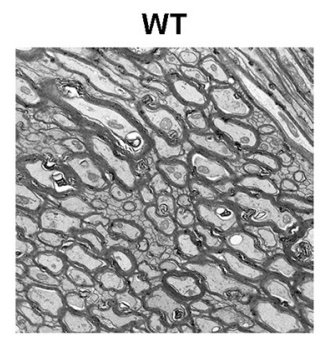

WT

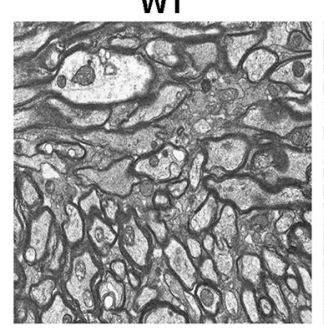

B

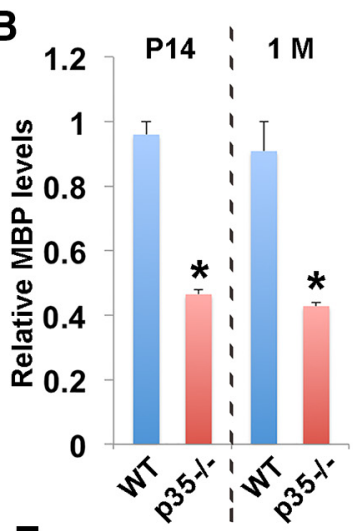

P35- -

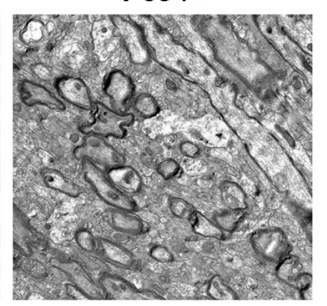

P39-/-

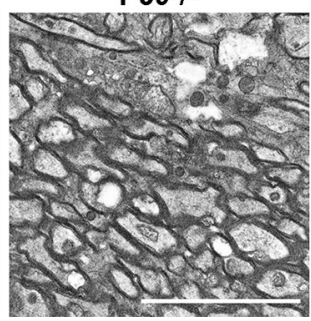

E
C

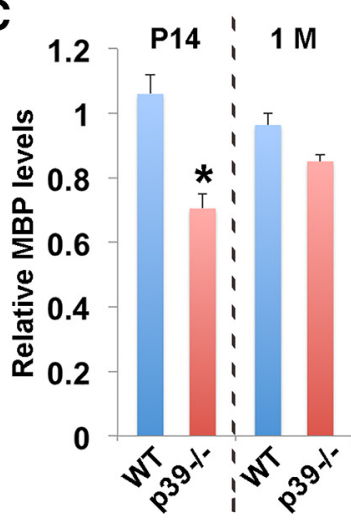

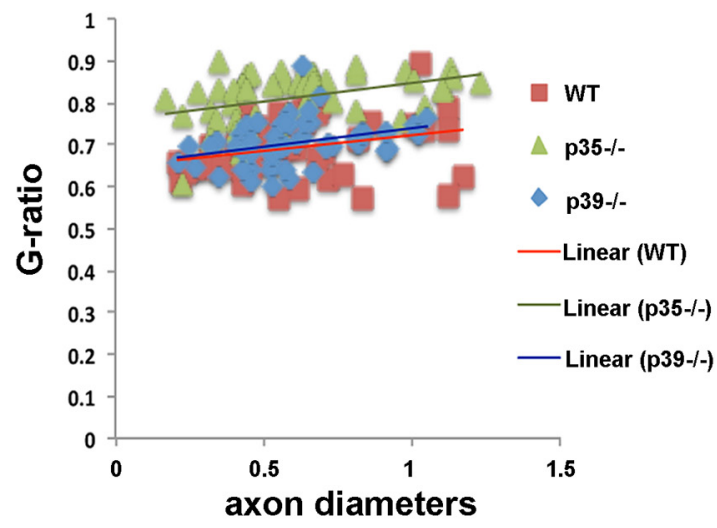

Figure 5. Quantitative analysis of myelination in the brains of $p 35^{-1-}$ and $p 39^{-1-}$ mice. Extracted proteins from subcortical white matter were examined by Western blot analysis (A). Reduction of MBP level at P14 of $p 35^{-/-}$and $p 39^{-/-}$mice and reduced MBP were detected only in $p 35^{-/-}$at 1 month of age but not in $p 39^{-/-}$(A). Quantitative analysis was shown in $\boldsymbol{B}$ and C. EM analysis confirmed reduced myelin in the corpus callosum of adult $p 35^{-/-}$but not in adult $p 39^{-1-}$ (D). Relative G ratios are shown in $E$. Values are mean \pm SEM $(n=3)$. ${ }^{*} p<0.05$. Scale bar (in D): $25 \mu \mathrm{m}$.

Characterization of OL and myelin development in the brain of $p 35^{-/-}$and $p 39^{-1-}$ mice

To determine whether the loss of p35 or p39 altered the differentiation and maturation of OPC lineage cells in vivo, $20 \mu \mathrm{m}$ coronal sections through the corpus callosum and adjacent cortex of $p 35^{-/-}$and $p 39^{-/-}$mice were labeled with antibodies to Olig2, $\mathrm{CC} 1, \mathrm{MBP}$, and neurofilament at P7, P14, P21, and 1 and 2 months of age. Analysis of the number of Olig2 ${ }^{+}$cells did not reveal any significant difference between $p 35^{-/-}$and WT animals at any age assayed (Fig. $3 A, B$ ). In contrast, analysis of the number of $\mathrm{CCl}^{+}$cells in $p 35^{-/-}$animals revealed a significant decrease compared with age-matched WT sections at P7, P14, P21, and 1 month of age (Fig. $3 A, B$ ), consistent with the hypothesis that 335 plays a role in the differentiation of OPCs. The effect of p39 loss was less pronounced than that of $\mathrm{p} 35$. There was no significant difference in the density of Olig2 ${ }^{+}$cells, and the density of $\mathrm{CC} 1{ }^{+}$ cells was significantly different only at P7 and P14. By P21, the density of $\mathrm{CC}^{+}$cells was similar to that of WT littermate controls, suggesting that p39 has a more limited role in regulating the development of OLs. In addition, no significant difference was seen in axon diameters of corpus callosum among $p 35^{-/-}$, p39 $9^{-/-}$, and WT mice.

Changes in myelination levels reflected the changes in $\mathrm{CC}^{+}$ cell numbers. In $p 35^{-/-}$animals, the organization of the subcortical white matter was severely disrupted (Fig. 4A) and the expres- sion of MBP was significantly reduced (Fig. 4A) throughout development. However, in $p 39^{-/-}$animals, a reduction of MBP was evident only at P14, and this was relatively minor (Fig. 4B). Quantitation of protein levels by Western blot analysis confirmed a reduction in MBP expression at both $\mathrm{P} 14$ and 1 month of age in $p 35^{-1-}$ animals (Fig. $5 A, B$ ), whereas the only significant reduction in MBP level was seen at p14 in $p 39^{-/-}$animals (Fig. $5 A, C$ ). Ultrastructural studies confirmed a reduction in myelination in $p 35^{-1-}$ animals at 2 months of age (Fig. 5D) that included a reduction in the proportion of myelinated axons and a reduction in relative myelin thickness shown by changes in the $G$ ratio. Animals lacking p39 had no significant differences in the levels of myelination in the corpus callosum (Fig. 5D). The profile of changes in myelination in $p 35^{-/-}$and $p 39^{-/-}$animals is similar to that seen in purified cultures of OPCs, but particularly $p 35^{-/-}$ animals had a significant disruption of neuronal patterning that may contribute indirectly to changes in MBP expression. To unambiguously define the relative roles of OL lineage-expressed p35 and p39 in CNS myelination, a heterogenetic organotypic cerebellar slice preparation was used (Najm et al., 2013).

Differential myelination capacity of $p 35^{-/-}$and $p 39^{-/-}$OLs in organotypic slice cultures

To directly assess the effects of loss of p35 and p39 in cells of the OL lineage on their capacity for myelination, we used a hetero- 
A

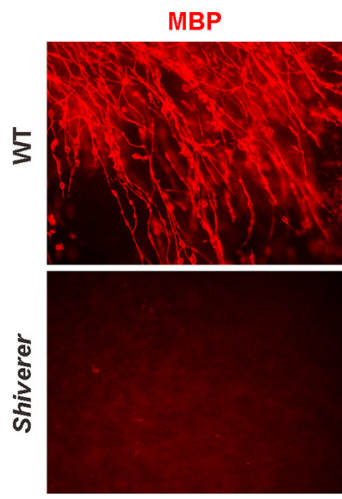

B

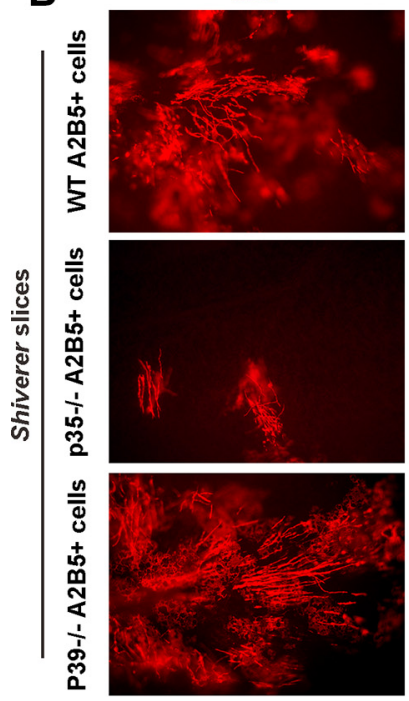

C

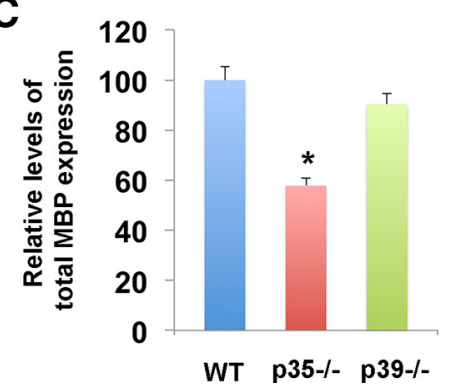

NF 200

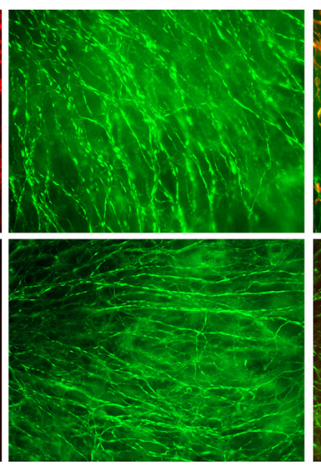

NF 200

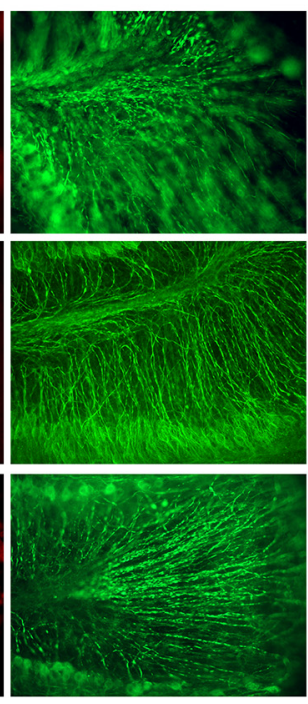

D

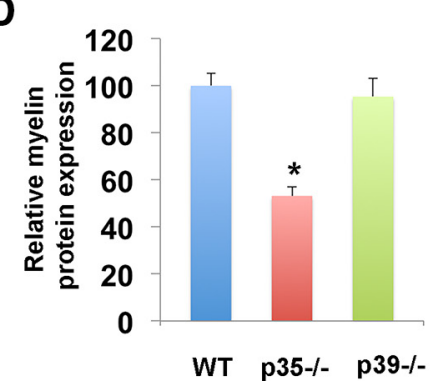

Figure 6. Partially inhibition of myelination of transplanted $p 35^{-/-}$or $p 39^{-/-} \mathrm{OPCs}$ in dysmyelinating shiverer organotypic cerebellar slice cultures. $A$, As a positive control, cerebellar slice culture from P6 C57BL/6 WT mice were grown for $10 \mathrm{~d}$ and labeled with MBP (red) and neurofilament 200 (NF 200; green) antibodies. No myelination was seen in shiverer slice culture (A). $\boldsymbol{B}$, Purified WT OPCs, $p 35^{-/-} \mathrm{OPC} s$, and $p 39^{-/-} \mathrm{OPC}$ were transplanted in shiverer slices and allowed for differentiation and myelination for $10 \mathrm{~d}$ in vitro and immunostained with MBP and neurofilament 200 (NF 200) antibodies. Quantitative bar graphs illustrate the relative levels of total MBP expression ( $C$ ) and the relative levels of MBP coexpressed with neurofilament (NF 200; $D$ ) in the shiverer slices after transplantation of WT, $p 35^{-/-}$, or $p 39^{-/-} \mathrm{OPC}$, respectively. Values are mean $\pm \mathrm{SEM}(n=3$ for each experiment, a minimum of $6-7$ slices were analyzed in per condition). ${ }^{*} p<0.05$. Scale bars: $A, B, 100 \mu \mathrm{m}$.

genetic organotypic cerebellar slice culture model (Najm et al., 2013). In this model, $p 35^{-/-}$or $p 39^{-/-}$cells are integrated into a cerebellar slice culture from shiverer animals that lacks MBP. Detection of MBP allows the visualization and quantitation of myelination by transplanted cells. In control slices of P6 WT cerebellum grown for $10 \mathrm{~d}$, there was extensive MBP labeling that was coincident with neurofilament-positive axons (Fig. 6A). In contrast, in parallel shiverer-derived slices, although there was extensive axonal outgrowth, there was a complete absence of MBP (Fig. 6A). Integration of purified WT OPCs into shiverer slices resulted in extensive expression of MBP after $10 \mathrm{~d}$ in culture that was oriented along axons (Fig. 6B). Integration of a similar number of purified $p 35^{-/-}$ OPCs in parallel shiverer slices resulted in dramatically lower levels of MBP expression. Not only were the number of $\mathrm{MBP}^{+}$ cells reduced but also their processes mostly lacked alignment with cerebellar axons (Fig. 6B-D). Integration of similar numbers of $p 39^{-1-}$ purified OPCs into shiverer slices generated levels of $\mathrm{MBP}$ similar to that seen in WT cells (Fig. $6 B-$ $D)$, suggesting that lack of p35 has a more pronounced effect than the lack of p39 on the capacity of OPCs to generate myelin.

\section{Partial compensation of expression of} p35 and p39 in the OL lineage

Individual loss of p35 and p39 resulted in a partial reduction in the myelinogenic capacity of OLs, suggesting the potential for compensatory expression. Quantitative Western blot analyses of purified OL lineage cells demonstrated elevated levels of p35 expression in cells lacking p39 that increased with differentiation (Fig. $7 A, B)$. Similarly, the relative levels of p39 were increased in cells lacking p35 (Fig. $7 C)$, suggesting compensatory expression. Consistent with the in vitro data, the relative levels of p 35 were elevated in subcortical white matter of $p 39^{-/-}$animals, whereas the relative levels of p39 were elevated in subcortical white matter of p35 $5^{-/-}$animals compared with controls (Fig. 7D-F). Together, these data suggest that the coordinated expression of p35 and p39 may functionally compensate for each other.

To determine the extent of functional compensation between p35 and p39 during OPC differentiation and myelination, purified $p 35^{-/-}$OPCs were electroporated with shRNA for p39 tagged with EGFP using Amaxa Nucleofector, and their differentiation was assayed. Electroporation of scrambled shRNA did not significantly affect the development of $p 35^{-1-}$ OPCs as marked by expression of O4, O1, and MBP immunoreactivity (Fig. $8 A)$. In contrast, electroporation of p 39 shRNA into $p 35^{-/-}$cells completely suppressed OPC development, although GFP expression revealed remaining process-bearing cells (Fig. $8 \mathrm{~A}$ ), indicating that the capacity of cells lacking both p35 and p39 to progress to myelinating cells was completely compromised.

To assess whether the differentiation of $p 35^{-/-} ;$p39 shRNA OPCs could be rescued by a neuronal environment, they were introduced into shiverer slices and the expression of MBP was assayed. OL precursors derived from $p 35^{-/-}$animals transfected with shRNA for p39 and identified by GFP expression failed to generate detectable MBP in shiverer slices even when maintained 

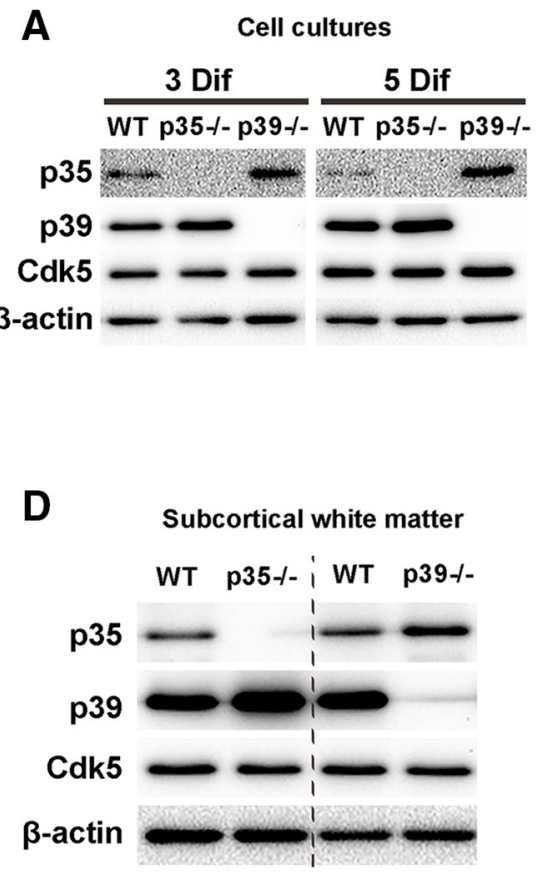

B

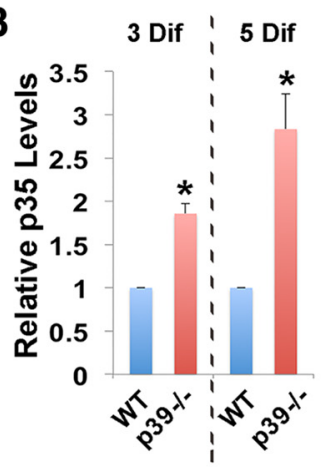

E

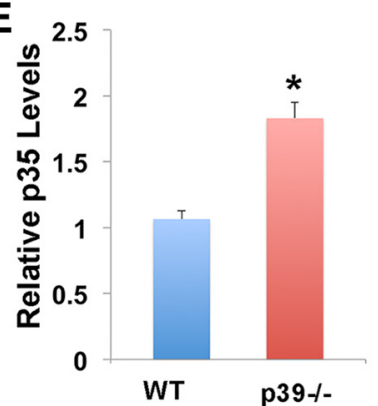

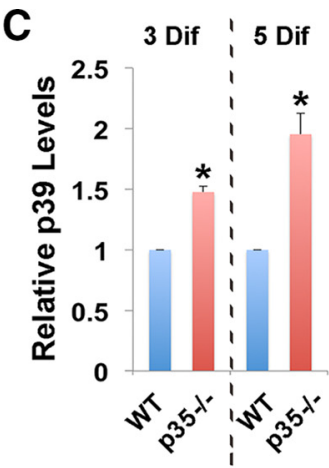

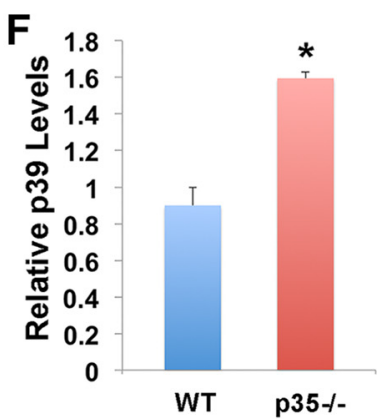

Figure 7. Increased expression of P35 or p39 in the cells of $0 \mathrm{~L}$ lineage lacking p39 or p35, respectively. $\boldsymbol{A}$, In vitro, Western blots showed increased levels of p35 protein expression in purified $p 39^{-1-}$ OPC cells, as well as increased p39 protein expression found in purified $p 35^{-/-}$cells at differentiation days 3 and 5 in cell cultures. Quantitative data are shown in $\boldsymbol{B}$ and $\boldsymbol{C}$. In vivo, similar findings were observed in the $p 35^{-/-}$and $p 39^{-/-}$mice at age 1 month $(\boldsymbol{D}-\boldsymbol{F})$. No changes were seen in (dk5 protein expression among adult WT, $p 35^{-/-}$, and $p 39^{-/-}$mice. Values are mean \pm $\operatorname{SEM}(n=3) .{ }^{*} p<0.05$.

for up to $10 \mathrm{~d}$, whereas WT cells elaborated extensive $\mathrm{MBP}^{+}$ processes (Fig. $8 B, C$ ). The primary role of $\mathrm{p} 35 / \mathrm{p} 39$ is thought to be activators of Cdk5, and it was anticipated that $C d k 5^{-/-}$cells would demonstrate a phenotype identical to $p 35^{-/-} ;$p39 shRNA cells when transplanted to shiverer slices. Somewhat unexpect-

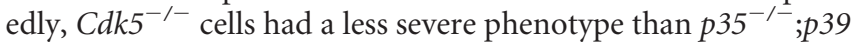
shRNA cells in that they elaborated $\mathrm{MBP}^{+}$processes, although compared with WT cells, they were significantly shorter and not oriented along axons (Fig. $8 B a, B c, B g, C, D$ ). To determine whether the overexpression of $\mathrm{Cdk} 5$ could rescue the myelination defect of $p 35^{-/-} ;$p39 shRNA cells, $p 35^{-/-}$cells were cotransfected with both $\mathrm{p} 39$ shRNA tagged with GFP and an overexpression construct of Cdk5 and added to shiverer slices. No rescue of the myelin defect was detected, consistent with the role of p35/ p39 as activators rather than inducers of Cdk5 (Fig. $8 B a, B b, C$ ) or working through a Cdk5 independent pathway. In contrast, the myelination defect of $C d k 5^{-/-}$cells could be rescued after Cdk5 overexpression (Fig. $8 B c, B d, C$ ). Furthermore, knockdown of either p35 or p39 in $C d k 5^{-/-}$OPCs showed an additive and more severe myelination defect than in $C d k 5^{-/-}$cells alone (Fig. $8 B c, B e, B f, C)$.

These studies suggest that p35 and/or p39 are critical for OL development and myelination. Although a major target of p35 and p39 activity is Cdk5, the difference in phenotype severity between cells lacking Cdk5 and both p35/39 and their additive nature suggests that $\mathrm{p} 35 / 39$ may have additional non-Cdk5 functions in OL development.

Decreased Cdk5 activity and reduced levels of phosphorylation of Cdk5, Akt, Gsk-3 $\beta$, and CREB in $p 35^{-/-}$; p39 shRNA cells

OL differentiation and myelination are influenced by a number of positive (CREB, Akt) or negative (Gsk-3 $\beta$ ) intracellular signaling pathways (Sato-Bigbee et al., 1999; Flores et al., 2008; Azim and Butt, 2011; Fyffe-Maricich et al., 2011). To elucidate whether Cdk5 activity was affected by the lack of p35/p39, the activity of Cdk5 was assayed using crosslink immunoprecipitation and in vitro kinase assay. Decreased kinase activity of Cdk5 was observed by measuring the levels of phosphorylated Histone 1 in $p 35^{-/-}$; p39 shRNA OPCs compared with WT OPCs (Fig. 9C). In addition, the levels of p-Cdk5, p-Akt, p-Gsk-3 $\beta$ (Ser 9), and p-CREB were significantly reduced in $p 35^{-1-} ; p 39$ shRNA and $C d k 5^{-1-}$ cells when compared with WT cells. However, the phosphorylation levels of CREB in $p 35^{-/-} ; p 39$ shRNA cells was significantly lower than in $C d k 5^{-/-}$cells, although there were no significant changes in the total protein levels in the absence of p35 and p39 (Fig. 9A,B), suggesting CREB as a potential target for p35 and p39. Together, these data suggest that p35/p39 are important for the activity of Cdk5 and its downstream targets that regulate OPC differentiation and myelination through both positive and negative signaling pathways.

\section{Discussion}

Multiple aspects of neurogenesis are influenced by Cdk5 (Lagace et al., 2008; Su and Tsai, 2011). Emerging evidence also implicates a role for Cdk5 in OL development, myelination, and remyelination (He et al., 2011b; Yang et al., 2013; Luo et al., 2014). How the functions of Cdk5 are regulated in the OL lineages is currently unknown. The only known activators of Cdk5 are the cyclin-like proteins p35 and p39, and, by analogy with their role in neuronal development (Ko et al., 2001), we assayed their relative importance in OL development and show that OL lineage cells require p35 and p39 to complete their developmental program both in vitro and in vivo.

Loss of either p35 or p39 disrupts oligodendrogenesis, but the influence of their loss is not equal. Morphological analyses demonstrated that p35 mediates process outgrowth and the transition 
A
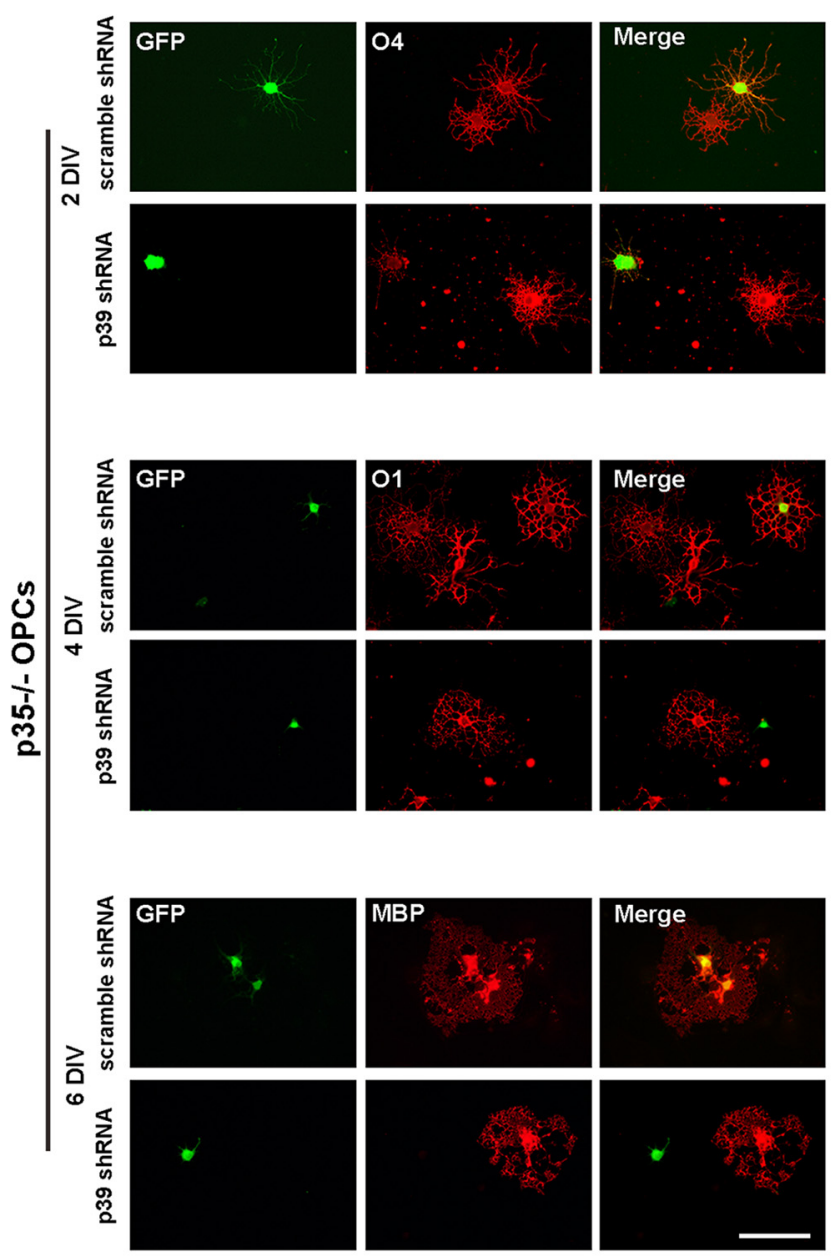

B

Shiverer slices
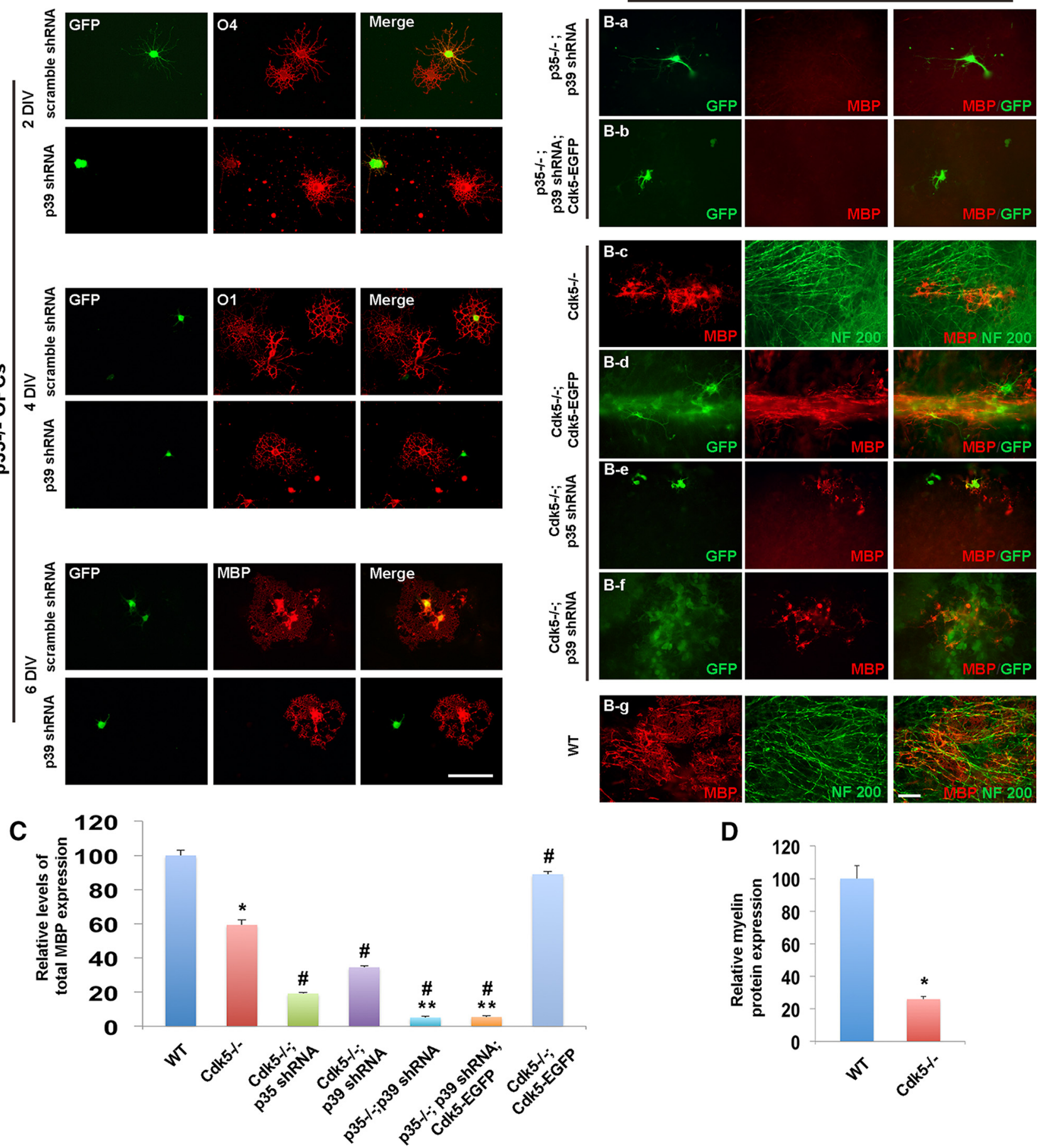

D

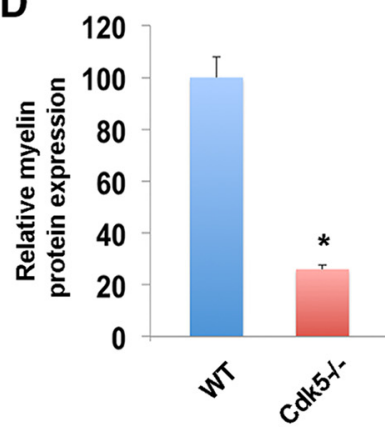

Figure 8. Loss both $\mathrm{p} 35$ and $\mathrm{p} 39$ in the cells of $0 \mathrm{~L}$ lineage completely blocks OPC differentiation and myelination. A, Purified $p 35^{-/-}$OPCs transfected with p39 shRNA-EGFP tagged cells (green) are shown coexpressed with early $\mathrm{OPCs}\left(\mathrm{O4}^{+}\right.$; top) with reduced cell processes. Transfected GFP ${ }^{+}$cells did not express with either immature $01^{+}$(red, middle) or mature MBP ${ }^{+}$cells (red, bottom) compared with cells transfected with scramble shRNA. B, Myelination assay in demyelinating shiverer slice culture. $p 35^{-/-} ;$; 39 shRNA (a), p35 ${ }^{-/} ;$; 39 shRNA;Cdk5-EGFP (b), Cdk5 $5^{-/[m i n u s]}$ (c),

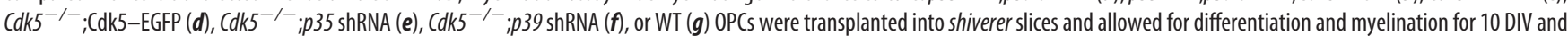
immunostained with GFP, MBP, and neurofilament 200 (NF 200) antibodies. Quantitative data are shown in bar graphs. Cand D illustrate the total relative level of MBP expression and the relative

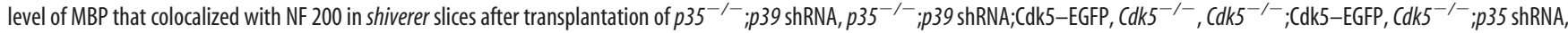
$C d k 5^{-1-} ; p 39$ shRNA, or WT OPCs. Values are mean \pm SEM ( $n=3$ per experiment, a minimum of $6-7$ slices were analyzed per condition). ${ }^{*} p<0.05$ versus WT, ${ }^{* *} p<0.01$ versus WT, ${ }^{\#} p<0.05$ versus $C \mathrm{dk5^{-/- }}$. Scale bars: $A, B, 100 \mu \mathrm{m}$.

of $\mathrm{O}^{+}$progenitor cells into immature $\mathrm{O} 1^{+}$cells. In vivo axonal pathways and the levels of myelination were severely affected by the loss of p35. The specific functions of p39 are less evident and primarily contribute to the transition from $\mathrm{O}^{+}$to mature
$\mathrm{MBP}^{+}$OLs. In vivo loss of $\mathrm{p} 39$ resulted in a mild phenotype of a transient delay of OL maturation. Single knock-out studies suggest that p35 and p39 have distinct functions during oligodendrogenesis that reflect specific activation of Cdk5. However, 
A
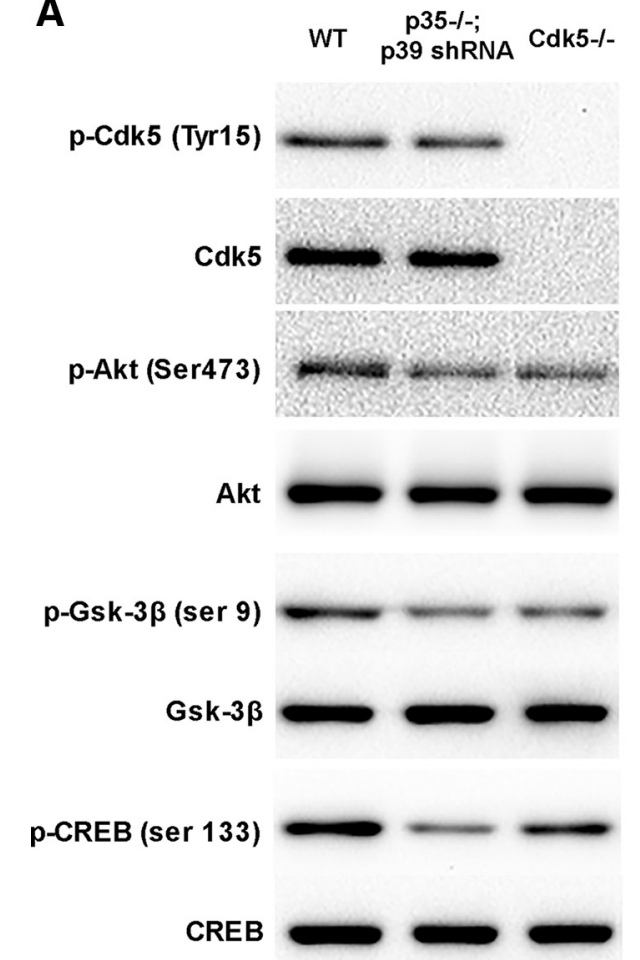

p- $\beta$-catenin

(Ser33/37/Thr41)

$\beta$-catenin
B

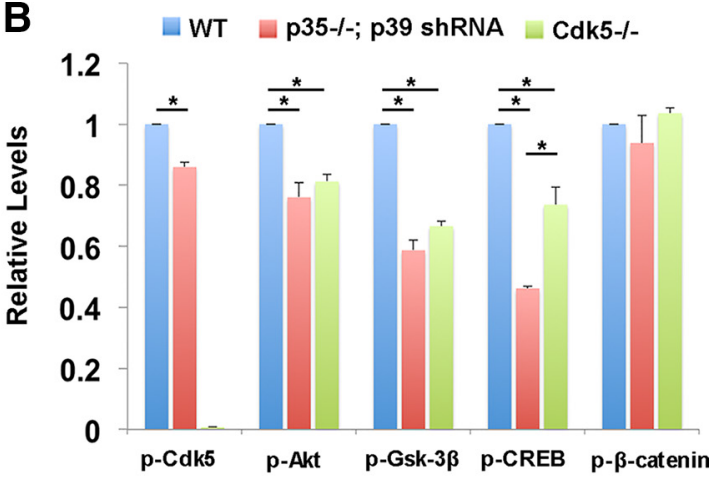

C

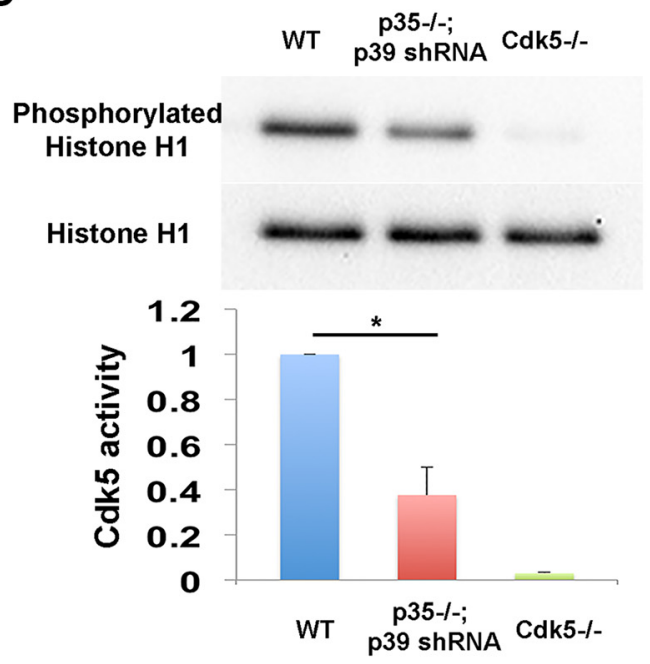

Figure 9. The changes of Cdk5 activity and downstream signaling pathways in $p 35^{-/-} ;$; 39 shRNA OPCs. A, Western blotting of p-Cdk5 (Tyr15), Cdk5;p-Akt (Ser473), Akt;p-Gsk-3 $\beta$ (Ser 9), Gsk-3 $\beta, p$-CREB (Ser133), CREB; $p$ - $\beta$-catenin (Ser33/37/Thr41), $\beta$-catenin in WT, $p 35^{-/} ; p 39$ shRNA, or Cdk5 $5^{-/-}$OPCs at day 3 of the differentiation period. B, Quantitative protein levels of

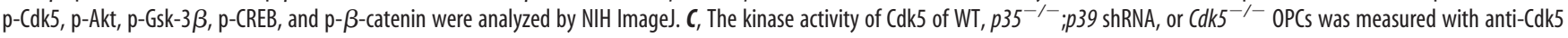
immunoprecipitates using Histone $\mathrm{H} 1$ as a substrate. The levels of phosphorylated Histone $\mathrm{H} 1$ were determined by Western blots using phosphorylated MAPK/Cdk antibody (top).

several lines of evidence indicate that $\mathrm{p} 35$ and p39 are at least partially capable of compensating for each other. For example, compared with WT controls, in $p 35^{-/-}$mutants, the levels of p39 are elevated, whereas in $p 39^{--}$mutants, the levels of p35 are elevated. More compelling is the finding that loss of both p35 and p39 results in a more profound phenotype than loss of either activator alone and results in a complete inhibition of OL maturation and myelination. The best known functions of p35/p39 are activators of Cdk5 (Ko et al., 2001), and the finding that the phenotype of OL lineage cell lacking both p35 and p39 was significantly worse than the phenotype of OL lineage cells lacking $C d k 5^{-1-}$ raises the possibility they have additional functions or targets in the OL lineage independent of Cdk5.

The timing of p35 and p39 expression during OL development and their relative influence of individual loss support the notion they have separate but overlapping functions. Early in development, p35 not p39 is predominantly expressed and its loss profoundly affects OPCs. In contrast, loss of p39 has less influence because p35 is already expressed and is upregulated as a result of p39 loss. This hypothesis, although consistent with our developmental data, is less consistent with studies suggesting that $\mathrm{p} 39$, but not $\mathrm{p} 35$, is the primary Cdk5 activator during OL differentiation and remyelination in the adult CNS (Bankston et al., 2013). The difference in these results might reflect the different animal species and techniques used by Bankston and colleagues but also imply that the regulation of Cdk5 activity is more complex than currently appreciated. It may be that, in the setting of remyelination, recruitment of adult OPCs does not require p35, whereas differentiation of those cells is in part p39 dependent. Such a model is supported by our finding that p 39 influences OL maturation and myelination.

The current study implicates p35 as a major activator of Cdk5 during OL development and myelination, but how p35 expression levels are regulated in the OL lineage is unclear. Previous studies in neurons have indicated that p35 gene expression is induced by multiple external signals, including nerve growth factor, brain-derived neurotrophic factor, retinoic acid, 1,25dihydroxyvitamin D3, and laminin (Paglini et al., 1998; Harada et al., 2001; Chen et al., 2004; Lee and Kim, 2004; Song et al., 2005; Shah and Lahiri, 2014). The upregulation of $\mathrm{p} 35$ expression by these factors may be mediated through activation of either the ERK1/2 or PI3K pathway (Harada et al., 2001; Song et al., 2005). Transcription factors, such as Hsf2, Brn-1, and Brn-2, are also involved (McEvilly et al., 2002; Chang et al., 2006) and tightly linked to the regulation of OL development (Schreiber et al., 1997; Stacchiotti et al., 1999; Homma et al., 2007). It is plausible that p35/p39 might function as a point of convergence for signaling through these distinct pathways. In this scenario, through control of Cdk5 activity, p35/39 integrate input from different 
pathways and fine-tune the rate and extent of OPCs differentiation and myelination.

The morphological development of OL lineage cells was reduced in the absence of p 35 , suggesting that p35-Cdk5 interacts with cytoskeletal components and that disrupted cytoskeleton influences the capacity of OL myelination (Zuchero et al., 2015). In neurons, p35-Cdk5 has been proposed to contribute to formation of actin-based structures such as dendritic spines, as well as general morphogenesis and motility (Su and Tsai, 2011; Lai and Ip, 2015). This likely reflects the capacity of p35 to directly bind to F-actin and mediate cytoskeletal reorganization (He et al., 2011a). In addition, Tau and WAVE1, two downstream targets of Cdk5, have been shown to be important for OL morphogenesis and normal CNS myelination (Kim et al., 2006; Miyamoto et al., 2008; Seiberlich et al., 2015). It seems likely that the perturbation of OL morphology and reduced myelination seen in the absence of p35 reflect both its direct interaction with actin filaments and disruption of downstream targets of Cdk5. The precise role of the different components remains to be resolved.

The significant disruption in the patterning of axonal trajectories and myelination in $p 35^{-/-}$mice and the lesser effects in $p 39^{-1-}$ animals may reflect the loss of p35 in both neuronal and OL lineage cells. Our in vitro studies unambiguously demonstrate a cell-autonomous role for both p35 and p39 in cells of the OL lineage. What is currently unclear is what the relative contribution to the in vivo phenotype of p35/p39 loss in neurons versus glia. Indeed, it has never been excluded that part of the neuronal phenotype in the $C d k 5^{-1-}, p 35^{-1-}$, and $p 39^{-/-}$animals is attributable to defects in their associated OL lineage cells. Clearly, the development and function of neuronal and OL lineage cells are closely linked, and loss of myelinating OLs is not compatible with long-term survival. It is notable that, in neurons as in OLs, the loss p35 is more detrimental to Cdk5 activity than is the loss of $\mathrm{p} 39$.

Both p35 and p39 are believed to exert their primary functions through interactions with Cdk5 that help regulate its activity and substrate preference (Ko et al., 2001; Shah and Lahiri, 2014). Previous studies have demonstrated that double knock-out $p 35^{-1-} ; p 39^{-1-}$ animals have a perinatal lethal phenotype that is a near perfect mimic of $C d k 5^{-/-}$animals (Ko et al., 2001). In the present study, in the OL lineage, we find that the loss of both p35 and p39 generates a stronger phenotype than the loss of Cdk5 alone for differentiation and myelination. Loss of Cdk5 alone results in delayed maturation, but the cells retained the ability to generated MBP in shiverer slice cultures, unlike the $p 35 / 39^{-/-}$ cells that failed to generate any MBP, suggest that p35 and p39 participate in the regulation of OL development in part through a Cdk5-independent pathway.

The idea of a Cdk5-independent p35/39 function is consistent with previous studies. Several p35 binding proteins have been identified in neurons, including $\beta$-catenin, E-cadherin precursor, neurofilament subunits, and tau (Kesavapany et al., 2001; Hou et al., 2007; He et al., 2008; Lin et al., 2008). p35 and p39 may interact with the $\alpha$-subunit of $\mathrm{Ca}^{2+/} /$ calmodulin-dependent protein kinase II and $\alpha$-actinin- 1 in a calcium-dependent manner (Dhavan et al., 2002). Furthermore, a recent study showed that p35 could modulate gene transcription through regulating nucleocytoplasmic shuttling of transcription regulators, such as nuclear hormone receptor coregulator-interacting factor 1 , independent of Cdk5 activity (Zhao et al., 2014). p35/Cdk5 may also regulate transcription at multiple levels that include interaction with histone deacetylase complexes (Li et al., 2004; Fu et al., 2013). Finally, the p35 degradation product p25 is capable of binding directly to Gsk-3 $\beta$
(Chow et al., 2014). Our immunocytochemical data indicate that a significant fraction of p35 and p39 has a nuclear localization in OL lineage cells, suggesting that they may be involved in transcriptional control during OPCs differentiation.

In summary, our studies provide evidence that p35 and p39 are critical regulators of OPC differentiation, maturation, and myelination and that p35 and p39 regulate OL development either through Cdk5-dependent activity or Cdk5-independent pathways. These findings will facilitate identification of upstream regulators of p35 and p39 and allow for the development of new avenues for therapeutic intervention in demyelinating diseases.

\section{References}

Arif A (2012) Extraneuronal activities and regulatory mechanisms of the atypical cyclin-dependent kinase Cdk5. Biochem Pharmacol 84:985-993. CrossRef Medline

Azim K, Butt AM (2011) GSK3beta negatively regulates oligodendrocyte differentiation and myelination in vivo. Glia 59:540-553. CrossRef Medline

Bankston AN, Li W, Zhang H, Ku L, Liu G, Papa F, Zhao L, Bibb JA, Cambi F, Tiwari-Woodruff SK, Feng Y (2013) p39, the primary activator for cyclin-dependent kinase $5(\mathrm{Cdk} 5)$ in oligodendroglia, is essential for oligodendroglia differentiation and myelin repair. J Biol Chem 288: 18047-18057. CrossRef Medline

Baron W, Metz B, Bansal R, Hoekstra D, de Vries H (2000) PDGF and FGF-2 signaling in oligodendrocyte progenitor cells: regulation of proliferation and differentiation by multiple intracellular signaling pathways. Mol Cell Neurosci 15:314-329. CrossRef Medline

Barres BA, Hart IK, Coles HS, Burne JF, Voyvodic JT, Richardson WD, Raff MC (1992) Cell death and control of cell survival in the oligodendrocyte lineage. Cell 70:31-46. CrossRef Medline

Chae T, Kwon YT, Bronson R, Dikkes P, Li E, Tsai LH (1997) Mice lacking p35, a neuronal specific activator of Cdk5, display cortical lamination defects, seizures, and adult lethality. Neuron 18:29-42. CrossRef Medline

Chang Y, Ostling P, Akerfelt M, Trouillet D, Rallu M, Gitton Y, El Fatimy R, Fardeau V, Le Crom S, Morange M, Sistonen L, Mezger V (2006) Role of heat-shock factor 2 in cerebral cortex formation and as a regulator of p35 expression. Genes Dev 20:836-847. CrossRef Medline

Chen F, Wang Q, Wang X, Studzinski GP (2004) Up-regulation of Egr1 by 1,25-dihydroxyvitamin D3 contributes to increased expression of p35 activator of cyclin-dependent kinase 5 and consequent onset of the terminal phase of HL60 cell differentiation. Cancer Res 64:5425-5433. CrossRef Medline

Cheung ZH, Ip NY (2007) The roles of cyclin-dependent kinase 5 in dendrite and synapse development. Biotechnol J 2:949-957. CrossRef Medline

Cheung ZH, Ip NY (2012) Cdk5: a multifaceted kinase in neurodegenerative diseases. Trends Cell Biol 22:169-175. CrossRef Medline

Chow HM, Guo D, Zhou JC, Zhang GY, Li HF, Herrup K, Zhang J (2014) CDK5 activator protein p25 preferentially binds and activates GSK3beta. Proc Natl Acad Sci U S A 111:E4887-E4895. CrossRef Medline

Cicero S, Herrup K (2005) Cyclin-dependent kinase 5 is essential for neuronal cell cycle arrest and differentiation. J Neurosci 25:9658-9668. CrossRef Medline

Contreras-Vallejos E, Utreras E, Gonzalez-Billault C (2012) Going out of the brain: non-nervous system physiological and pathological functions of Cdk5. Cell Signal 24:44-52. CrossRef Medline

Dhavan R, Greer PL, Morabito MA, Orlando LR, Tsai LH (2002) The cyclin-dependent kinase 5 activators p35 and p39 interact with the alphasubunit of $\mathrm{Ca} 2+/$ calmodulin-dependent protein kinase II and alphaactinin-1 in a calcium-dependent manner. J Neurosci 22:7879-7891. Medline

Fang-Hu, Zhang HH, Yang BX, Huang JL, Shun JL, Kong FJ, Peng-Xu, Chen ZG, Lu JM (2015) Cdk5 contributes to inflammation-induced thermal hyperalgesia mediated by the p38 MAPK pathway in microglia. Brain Res 1619:166-175. CrossRef Medline

Flores AI, Narayanan SP, Morse EN, Shick HE, Yin X, Kidd G, Avila RL, Kirschner DA, Macklin WB (2008) Constitutively active Akt induces enhanced myelination in the CNS. J Neurosci 28:7174-7183. CrossRef Medline

Fu AK, Hung KW, Wong HH, Fu WY, Ip NY (2013) Cdk5 phosphorylates a 
component of the HDAC complex and regulates histone acetylation during neuronal cell death. Neuro-Signals 21:55-60. CrossRef Medline

Fyffe-Maricich SL, Karlo JC, Landreth GE, Miller RH (2011) The ERK2 mitogen-activated protein kinase regulates the timing of oligodendrocyte differentiation. J Neurosci 31:843-850. CrossRef Medline

Genoud S, Lappe-Siefke C, Goebbels S, Radtke F, Aguet M, Scherer SS, Suter U, Nave KA, Mantei N (2002) Notch1 control of oligodendrocyte differentiation in the spinal cord. J Cell Biol 158:709-718. CrossRef Medline

Guan JS, Su SC, Gao J, Joseph N, Xie Z, Zhou Y, Durak O, Zhang L, Zhu JJ, Clauser KR, Carr SA, Tsai LH (2011) Cdk5 is required for memory function and hippocampal plasticity via the cAMP signaling pathway. PLoS One 6:e25735. CrossRef Medline

Harada T, Morooka T, Ogawa S, Nishida E (2001) ERK induces p35, a neuron-specific activator of Cdk5, through induction of Egr1. Nat Cell Biol 3:453-459. CrossRef Medline

He L, Lu QR (2013) Coordinated control of oligodendrocyte development by extrinsic and intrinsic signaling cues. Neurosci Bull 29:129-143. CrossRef Medline

He L, Hou Z, Qi RZ (2008) Calmodulin binding and Cdk5 phosphorylation of p35 regulate its effect on microtubules. J Biol Chem 283:13252-13260. CrossRef Medline

He L, Zhang Z, Yu Y, Ahmed S, Cheung NS, Qi RZ (2011a) The neuronal p35 activator of Cdk5 is a novel F-actin binding and bundling protein. Cell Mol Life Sci 68:1633-1643. CrossRef Medline

He X, Takahashi S, Suzuki H, Hashikawa T, Kulkarni AB, Mikoshiba K, Ohshima T (2011b) Hypomyelination phenotype caused by impaired differentiation of oligodendrocytes in Emx1-cre mediated Cdk5 conditional knockout mice. Neurochem Res 36:1293-1303. CrossRef Medline

He Y, Li HL, Xie WY, Yang CZ, Yu AC, Wang Y (2007) The presence of active Cdk5 associated with p35 in astrocytes and its important role in process elongation of scratched astrocyte. Glia 55:573-583. CrossRef Medline

Homma S, Jin X, Wang G, Tu N, Min J, Yanasak N, Mivechi NF (2007) Demyelination, astrogliosis, and accumulation of ubiquitinated proteins, hallmarks of CNS disease in hsf1-deficient mice. J Neurosci 27:79747986. CrossRef Medline

Hou Z, Li Q, He L, Lim HY, Fu X, Cheung NS, Qi DX, Qi RZ (2007) Microtubule association of the neuronal p35 activator of Cdk5. J Biol Chem 282:18666-18670. CrossRef Medline

Kesavapany S, Lau KF, McLoughlin DM, Brownlees J, Ackerley S, Leigh PN, Shaw CE, Miller CC (2001) p35/cdk5 binds and phosphorylates betacatenin and regulates beta-catenin/presenilin-1 interaction. Eur J Neurosci 13:241-247. CrossRef Medline

Kim HJ, DiBernardo AB, Sloane JA, Rasband MN, Solomon D, Kosaras B, Kwak SP, Vartanian TK (2006) WAVE1 is required for oligodendrocyte morphogenesis and normal CNS myelination. J Neurosci 26:5849-5859. CrossRef Medline

Ko J, Humbert S, Bronson RT, Takahashi S, Kulkarni AB, Li E, Tsai LH (2001) p35 and p39 are essential for cyclin-dependent kinase 5 function during neurodevelopment. J Neurosci 21:6758-6771. Medline

Koenning M, Jackson S, Hay CM, Faux C, Kilpatrick TJ, Willingham M, Emery B (2012) Myelin gene regulatory factor is required for maintenance of myelin and mature oligodendrocyte identity in the adult CNS. J Neurosci 32:12528-12542. CrossRef Medline

Kwon YT, Tsai LH (1998) A novel disruption of cortical development in p35(-/-) mice distinct from reeler. J Comp Neurol 395:510-522. CrossRef Medline

Lagace DC, Benavides DR, Kansy JW, Mapelli M, Greengard P, Bibb JA, Eisch AJ (2008) Cdk5 is essential for adult hippocampal neurogenesis. Proc Natl Acad Sci U S A 105:18567-18571. CrossRef Medline

Lai KO, Ip NY (2015) Cdk5: a key player at neuronal synapse with diverse functions. Mini Rev Med Chem 15:390-395. CrossRef Medline

Lai KO, Wong AS, Cheung MC, Xu P, Liang Z, Lok KC, Xie H, Palko ME, Yung WH, Tessarollo L, Cheung ZH, Ip NY (2012) TrkB phosphorylation by Cdk5 is required for activity-dependent structural plasticity and spatial memory. Nat Neurosci 15:1506-1515. CrossRef Medline

Lebrun-Julien F, Bachmann L, Norrmén C, Trötzmuller M, Köfeler H, Rüegg MA, Hall MN, Suter U (2014) Balanced mTORC1 activity in oligodendrocytes is required for accurate CNS myelination. J Neurosci 34:84328448. CrossRef Medline

Lee JH, Kim KT (2004) Induction of cyclin-dependent kinase 5 and its activator p35 through the extracellular-signal-regulated kinase and protein kinase A pathways during retinoic-acid mediated neuronal differentiation in human neuroblastoma SK-N-BE(2)C cells. J Neurochem 91:634647. CrossRef Medline

Li Z, David G, Hung KW, DePinho RA, Fu AK, Ip NY (2004) Cdk5/p35 phosphorylates $\mathrm{mSds} 3$ and regulates $\mathrm{mSds} 3$-mediated repression of transcription. J Biol Chem 279:54438-54444. CrossRef Medline

Lin S, Wang J, Ye Z, Ip NY, Lin SC (2008) CDK5 activator p35 downregulates E-cadherin precursor independently of CDK5. FEBS Lett 582: 1197-1202. CrossRef Medline

Luo F, Burke K, Kantor C, Miller RH, Yang Y (2014) Cyclin-dependent kinase 5 mediates adult OPC maturation and myelin repair through modulation of Akt and GsK-3beta signaling. J Neurosci 34:10415-10429. CrossRef Medline

McEvilly RJ, de Diaz MO, Schonemann MD, Hooshmand F, Rosenfeld MG (2002) Transcriptional regulation of cortical neuron migration by POU domain factors. Science 295:1528-1532. CrossRef Medline

Miller RH (2002) Regulation of oligodendrocyte development in the vertebrate CNS. Prog Neurobiol 67:451-467. CrossRef Medline

Miyamoto Y, Yamauchi J, Chan JR, Okada A, Tomooka Y, Hisanaga S, Tanoue A (2007) Cdk5 regulates differentiation of oligodendrocyte precursor cells through the direct phosphorylation of paxillin. J Cell Sci 120:4355-4366. CrossRef Medline

Miyamoto Y, Yamauchi J, Tanoue A (2008) Cdk5 phosphorylation of WAVE2 regulates oligodendrocyte precursor cell migration through nonreceptor tyrosine kinase Fyn. J Neurosci 28:8326-8337. CrossRef Medline

Najm FJ, Zaremba A, Caprariello AV, Nayak S, Freundt EC, Scacheri PC, Miller RH, Tesar PJ (2011) Rapid and robust generation of functional oligodendrocyte progenitor cells from epiblast stem cells. Nat Methods 8:957-962. CrossRef Medline

Najm FJ, Lager AM, Zaremba A, Wyatt K, Caprariello AV, Factor DC, Karl RT, Maeda T, Miller RH, Tesar PJ (2013) Transcription factor-mediated reprogramming of fibroblasts to expandable, myelinogenic oligodendrocyte progenitor cells. Nat Biotechnol 31:426-433. CrossRef Medline

Najm FJ, Madhavan M, Zaremba A, Shick E, Karl RT, Factor DC, Miller TE, Nevin ZS, Kantor C, Sargent A, Quick KL, Schlatzer DM, Tang H, Papoian R, Brimacombe KR, Shen M, Boxer MB, Jadhav A, Robinson AP, Podojil JR, Miller SD, Miller RH, Tesar PJ (2015) Drug-based modulation of endogenous stem cells promotes functional remyelination in vivo. Nature 522:216-220. CrossRef Medline

Narayanan SP, Flores AI, Wang F, Macklin WB (2009) Akt signals through the mammalian target of rapamycin pathway to regulate CNS myelination. J Neurosci 29:6860-6870. CrossRef Medline

Paglini G, Pigino G, Kunda P, Morfini G, Maccioni R, Quiroga S, Ferreira A, Cáceres A (1998) Evidence for the participation of the neuron-specific CDK5 activator P35 during laminin-enhanced axonal growth. J Neurosci 18:9858-9869. Medline

Pritchard AJ, Mir AK, Dev KK (2014) Fingolimod attenuates splenocyteinduced demyelination in cerebellar slice cultures. PLoS One 9:e99444. CrossRef Medline

Sato-Bigbee C, Pal S, Chu AK (1999) Different neuroligands and signal transduction pathways stimulate CREB phosphorylation at specific developmental stages along oligodendrocyte differentiation. J Neurochem 72: 139-147. CrossRef Medline

Schreiber J, Enderich J, Sock E, Schmidt C, Richter-Landsberg C, Wegner M (1997) Redundancy of class III POU proteins in the oligodendrocyte lineage. J Biol Chem 272:32286-32293. CrossRef Medline

Seiberlich V, Bauer NG, Schwarz L, Ffrench-Constant C, Goldbaum O, Richter-Landsberg C (2015) Downregulation of the microtubule associated protein Tau impairs process outgrowth and myelin basic protein mRNA transport in oligodendrocytes. Glia 63:1621-1635. CrossRef Medline

Shah K, Lahiri DK (2014) Cdk5 activity in the brain-multiple paths of regulation. J Cell Sci 127:2391-2400. CrossRef Medline

Sheridan GK, Dev KK (2012) S1P1 receptor subtype inhibits demyelination and regulates chemokine release in cerebellar slice cultures. Glia 60: 382-392. CrossRef Medline

Smith DS, Greer PL, Tsai LH (2001) Cdk5 on the brain. Cell Growth Diff 12:277-283. Medline

Song JH, Wang CX, Song DK, Wang P, Shuaib A, Hao C (2005) Interferon gamma induces neurite outgrowth by up-regulation of p35 neuron- 
specific cyclin-dependent kinase 5 activator via activation of ERK1/2 pathway. J Biol Chem 280:12896-12901. CrossRef Medline

Stacchiotti A, Rezzani R, Rodella L, Tiberio L, Schiaffonati L, Bianchi R (1999) Cell-specific expression of heat shock transcription factors 1 and 2 in unstressed rat spinal cord. Neurosci Lett 268:73-76. CrossRef Medline

Su SC, Tsai LH (2011) Cyclin-dependent kinases in brain development and disease. Annu Rev Cell Dev Biol 27:465-491. CrossRef Medline

Sussman CR, Davies JE, Miller RH (2002) Extracellular and intracellular regulation of oligodendrocyte development: roles of Sonic hedgehog and expression of E proteins. Glia 40:55-64. CrossRef Medline

Tang XM, Strocchi P, Cambi F (1998) Changes in the activity of cdk2 and cdk5 accompany differentiation of rat primary oligodendrocytes. J Cell Biochem 68:128-137. CrossRef Medline

Tawk M, Makoukji J, Belle M, Fonte C, Trousson A, Hawkins T, Li H, Ghandour S, Schumacher M, Massaad C (2011) Wnt/beta-catenin signaling is an essential and direct driver of myelin gene expression and myelinogenesis. J Neurosci 31:3729-3742. CrossRef Medline

Wang J, Pol SU, Haberman AK, Wang C, O'Bara MA, Sim FJ (2014)
Transcription factor induction of human oligodendrocyte progenitor fate and differentiation. Proc Natl Acad Sci U S A 111:E2885-E2894. CrossRef Medline

Yang Y, Wang H, Zhang J, Luo F, Herrup K, Bibb JA, Lu R, Miller RH (2013) Cyclin dependent kinase 5 is required for the normal development of oligodendrocytes and myelin formation. Dev Biol 378:94-106. CrossRef Medline

Zhao XS, Fu WY, Chien WW, Li Z, Fu AK, Ip NY (2014) p35 regulates the CRM1-dependent nucleocytoplasmic shuttling of nuclear hormone receptor coregulator-interacting factor 1 (NIF-1). PLoS One 9:e110584. CrossRef Medline

Zhou Q, Choi G, Anderson DJ (2001) The bHLH transcription factor Olig2 promotes oligodendrocyte differentiation in collaboration with $\mathrm{Nkx} 2.2$. Neuron 31:791-807. CrossRef Medline

Zuchero JB, Fu MM, Sloan SA, Ibrahim A, Olson A, Zaremba A, Dugas JC, Wienbar S, Caprariello AV, Kantor C, Leonoudakis D, LariosaWillingham K, Kronenberg G, Gertz K, Soderling SH, Miller RH, Barres BA (2015) CNS myelin wrapping is driven by actin disassembly. Dev Cell 34:152-167. CrossRef Medline 